\title{
The Distribution of the Hesperiidae (Lepidoptera) Family in Romania
}

\author{
Cristina Costache, Maria-Milena FiliP, Andrei CrişAn \& László Rákosy
}

\begin{abstract}
Summary: In Romania, 24 Skippers species have been reported so far, of which 14 found in the foothills zone, 6 found in the lowlands zone, 2 found in the montane zone, one found in the subalpine zone and one found in the alpine zone. The diagnosis, biology and ecology data, distribution density (known area), conservation status have been specified for each species. The distribution of each species in Romania is illustrated by maps, occurrences of each species were divided into three periods (1850-1950, 1950-1989, 19902018) using distinct symbols. Muschampia cribrellum and M. tessellum, two very rare species found in Europe, should be included in the list of protected lepidoptera of European Union.
\end{abstract}

Key words: Skippers, Hesperiidae, Romania

\section{Introduction}

Lepidoptera represents an important link in most terrestrial ecosystems. They are pollinators for plants, prey for avifauna, sensitive indicators (BECCALONI and Gaston 1995, OostermeiJere and Van SwaAY 1998). Pollination represents a critical ecosystem service (OlLerTON et al. 2011, GARIBALDi et al. 2013). About $50 \%$ of European butterflies inhabit semi-natural grasslands maintained by traditional human activities (ERHARDT and THOMAs 1991).

All of the Hesperiidae species are important pollinators. They are related to the grassland habitat, being threatened with intensification and abandonment of land use and habitat fragmentation. Cessation of traditional grazing threatens biodiversity in Romania (Cremene et al. 2005, Schmitt and Rakosy 2007). The use of pesticides in agriculture and silviculture reaches protected areas, affecting massively the insect communities in Central Europe and Western Europe (Hallmann et al. 2017). The decline of entomofauna is widespread globally (SÁNCHEZ-BAYO and WYCKHUYS 2019).

According to the latest version of the Romanian Lepidoptera Catalog (RÁkosy and Goia in press), Romania is one of the countries that has the highest number of Lepidoptera species with more than 4000 species, of which 204 are diurnal, distributed altitudinally from the Black Sea shore to 2300-2400 m (Fig. 1). However, in Romania, while the problem of habitat loss is also present, the lack of updated data lessens an appropriate action.

The purpose of this paper is to review the data pertaining to the Hesperiidae family (Lepidoptera) living in Romania from most national and foreign available publications (Appendix 1). In addition, the Lepidoptera density distribution was considered, in order to present evidence in favor of proposing measures for the protection and conservation of endangered species.

\section{Methods and materials}

The distribution maps of the Hesperiidae over the Romanian territory were generated by compiling the data found in the literature known and accessible to us of faunistic or taxonomic nature, published from 1850 until recently, and those that attest the collection of any skipper. Specifically, data such as: species, location and date of collection, collector, as well as the number and sex of the specimens have been selected. Since GPS coordinates have been sparsely mentioned, we have inferred these data based on collection locations.

In addition to the published data, the following private collections have been examined in order to provide a more comprehensive assessment: László RÁkosy (Cluj), Marin Goia (Cluj), Levente SzÉKely (Săcele, Braşov), Constantin CoRdunEanu (Botoșani) and museum collections: "Gr. Antipa" National Natural History Museum, Bucarest (collection "Dr. Doc Aurelian POPESCU-GorJ", collection "Ludovic BeregszászY", collection "Dr. Levente SzÉKelY", collection "Ioan LĂZĂRESCU"), Zoological Museum of the Babeș Bolyai University, Cluj (coll. PÉTERFI).

Some species may be missing from the regions with no data due to intensive farming, loss of habitats 
through transformation into agricultural or urban land, etc. A more detailed study of this family in the south and east of the country is necessary in order to be able to accurately determine the area of the species and, if necessary, to implement appropriate protection and conservation measures.

Occurrences of each species were divided into three time intervals (1850-1950, 1950-1989, 1990-2018).

The maps were created using ArcGIS software (Environmental Systems Research Institute, 2015). Fig. 1 was generated using successively the following programs: ArcGIS (ESRI, 2015), Excel (MS Office, 2016) and Paint.net 4.2.6, based on the altitude data set, available on worldclim.com (HiJmANs et al. 2005).

The determinations were made according to the collections. The genetic determinations for the material that was available to us were from the collection of RÁKOSY, collection of PÉTERFI, and from newly collected data. In dubious specimens we have studied the genital armature for correct diagnosis. In order to avoid the confusion generated by some problematic species, data from published museum collection was used.

\section{Carterocephalus palaemon (PALLAS, 1771)}

\section{Diagnosis}

It is an unmistakable species in Romanian fauna.

Biology and Ecology

Carterocephalus palaemon is a univoltine species.

The life cycle of the chequered skipper starts in mid - May and ends slightly before July of the following year (RÁkosy 2013). Males exhibit a very territorial behavior. Most males choose multiple perches in order to guard and catch any potential mates that pass through their territory. It is a woodland species but it can be found in bogs, at the edges of streams and at grassy forest openings (EBERT and RENNWALD 1991). The nectar sources for adults consist in Ajuga reptans, A. genevensis, Sanguisorba minor, Sambucus racemose, Urtica dioica, Potentilla reptans, Trifolium repens, Potentilla reptans, Galium verum (EBERT and RENNWALD 1991, LAFRANCHIS et al. 2015).

Distribution

C. palaemon is a holarctic species (KUDRNA et al. 2011). In Romania it can be found in the center, west, north, north-east of the country (Fig. 2) It prefers higher altitudes and can be found as high as $1800 \mathrm{~m}$. Conservation

In Romania its status of conservation is least concern as in all the EU countries. (VAN SWAAY et al. 2014, RÁkosy et al. in press).

\section{Heteropterus morpheus (PALLAS, 1771)}

\section{Diagnosis}

It is an unmistakable species in Romanian fauna.

Biology and Ecology

Heteropterus morpheus is a univoltine species. The butterfly flies from May to June, depending on the location. Adults can be found at the edges of streams and grassy forest openings (RÁKosy 2013).

\section{Distribution}

It's an Eurasiatic species, found in the center, northern and southern Europe (KUDRNA et al. 2011). The species is found from Spain to Mongolia, north of

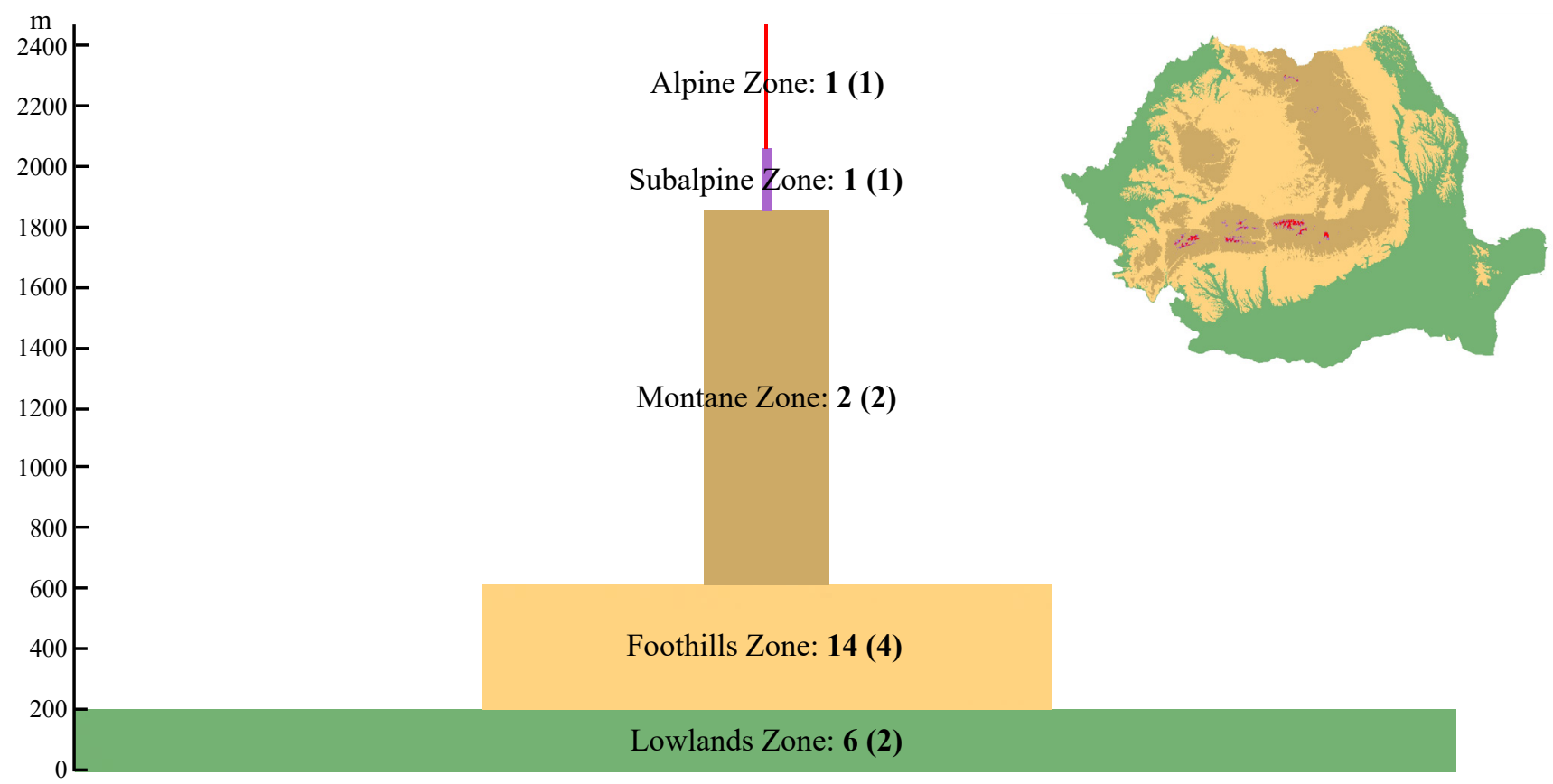

Fig. 1. The distribution by altitudinal levels of the 24 Romanian Skippers taxa. Conventionally, five zones were considered: between $0-200 \mathrm{~m}$, the lowlands zone ( $42 \%$ of the Romanian territory); between $200-600 \mathrm{~m}$, the foothills zone ( $35 \%$ of Romanian territory), between $600-1800 \mathrm{~m}$, the montane zone (22\% of the Romanian territory); between 1800-2000 m, the subalpine zone ( $0,3 \%$ of the Romanian territory) and over $2000 \mathrm{~m}$, the alpine zone $(0,2 \%$ of the Romanian territory). Between brackets: the number of species that may occur in other altitudinal zones; outside brackets: the species characteristic of that level. 
Observations

between 1991-2018

Observations

$\Delta$ between 1951-1990

- Observations

between $1850-1950$
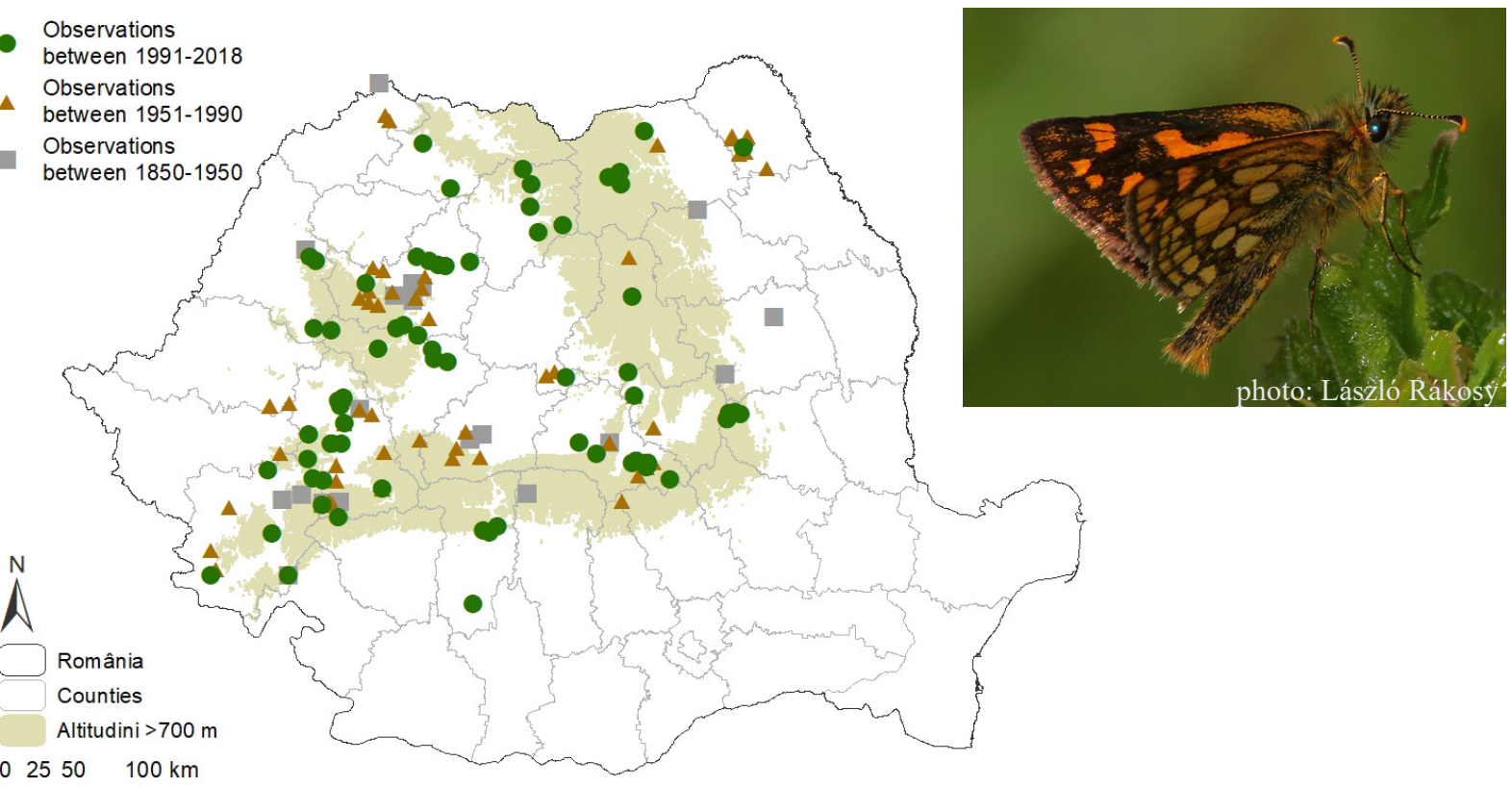

Fig. 2. Distribution map of Carterocephalus palaemon in Romania

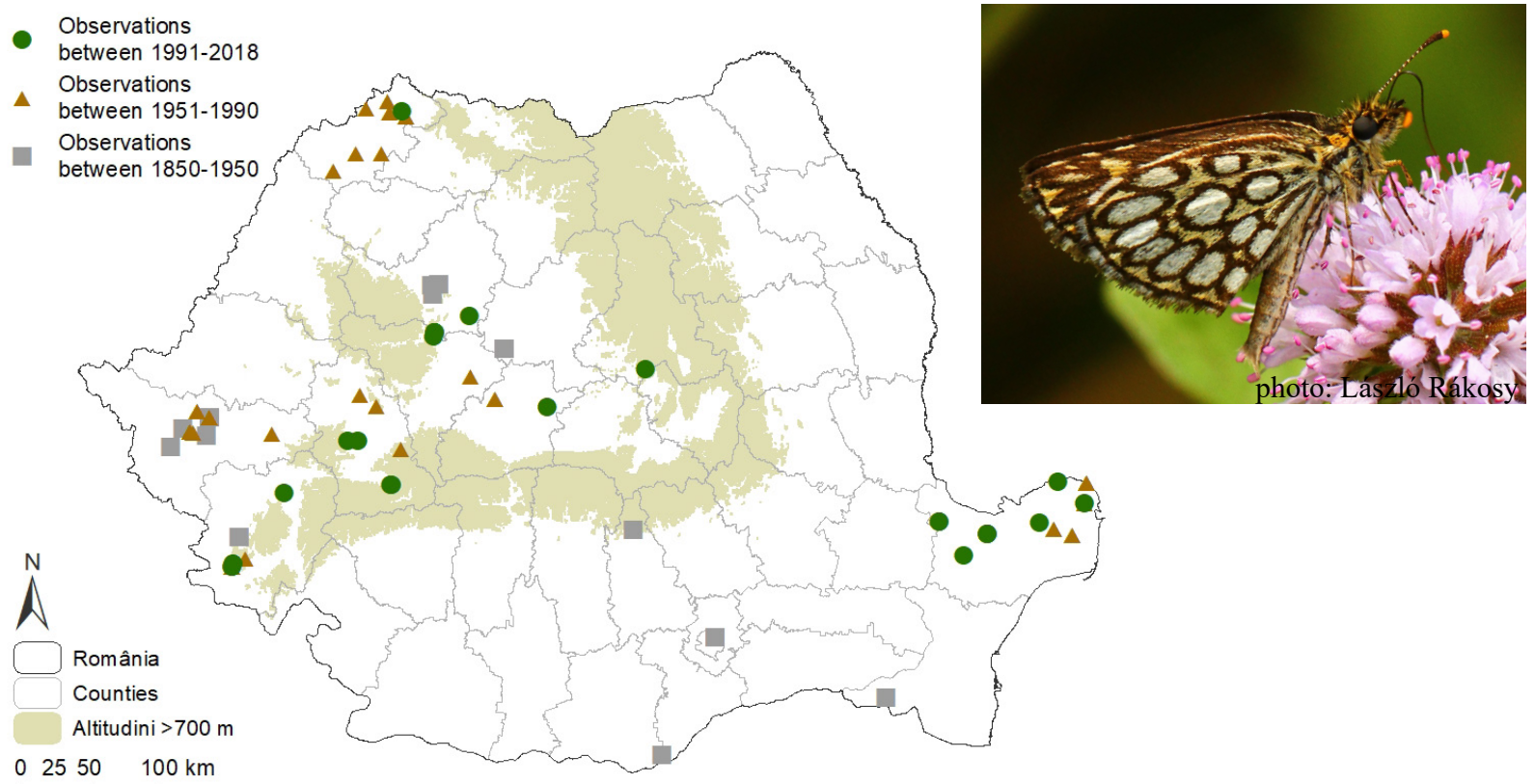

Fig. 3. Distribution map of Heteropterus morpheus in Romania

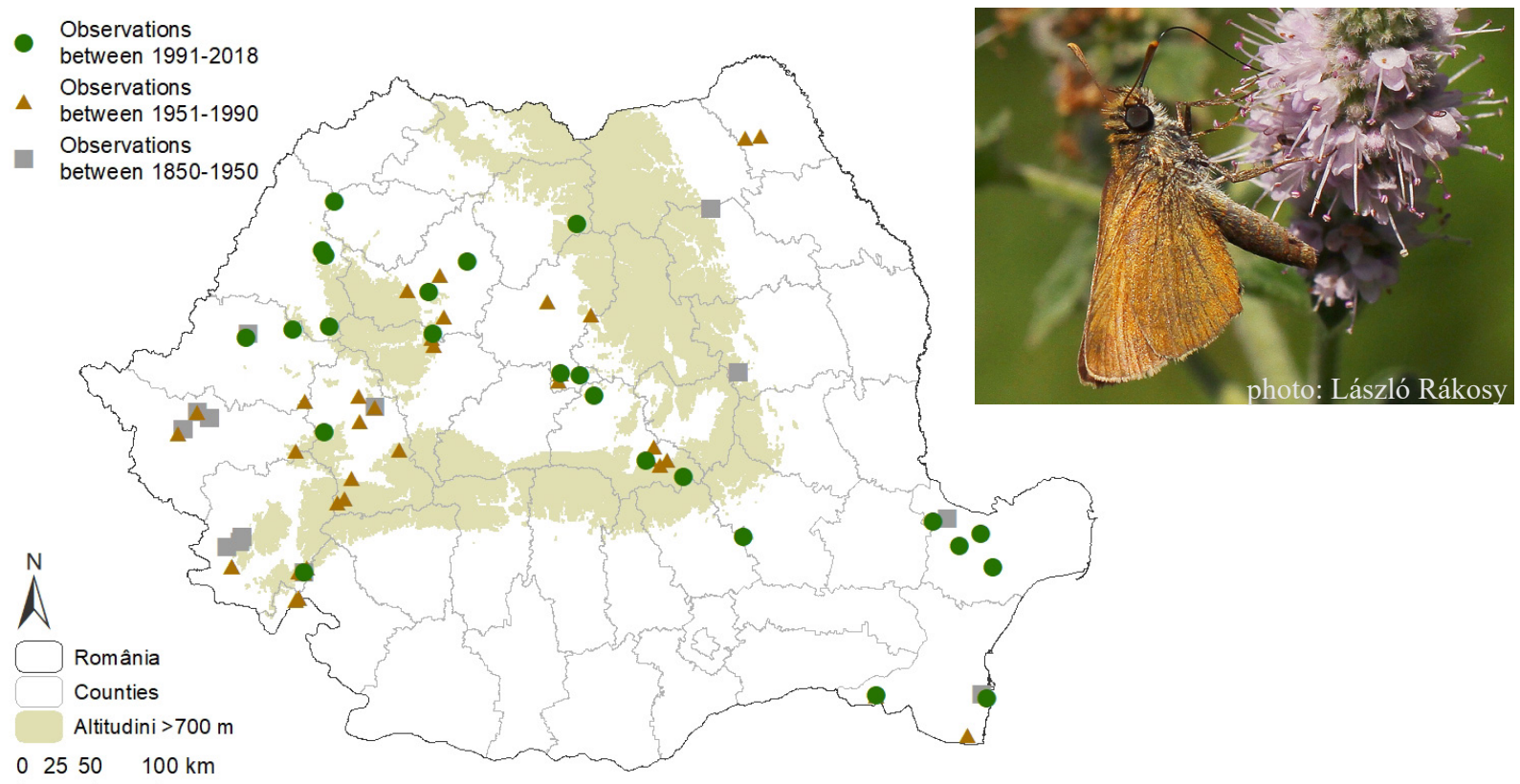

Fig. 4. Distribution map of Thymelicus acteon in Romania 
China and Korea (Tuzov 1997).

In Romania, $H$. morpheus has become increasingly rare over the past 50 years. It is more present in Banat and the Danube Delta (Fig. 3).

Conservation

The IUCN European status of Heteropterus morpheus is least concern. The Romanian Red List status is least concern but in some regions the status is near threatened. The worst threat is the habitat loss (VAN SWAAY et al. 2014, RÁKosy et al. in press).

Thymelicus acteon (RotTEMBURG, 1775)

\section{Diagnosis}

The upper and front of wings are distinguished by two yellow-orange spots, elongated and adjacent, on a brown background. On the outside there is a row of seven spots, also yellow-orange. Spots are more pronounced in females. In males, the spots are less colorful and their observation depends on an appropriate light angle. The males have androconial scales on the upper wings. The bottom of the wings is yellow and may have some light-yellow spots. Species determination is based on genital armature diagnosis, since Thymelicus acteon, T. lineola and $T$. sylvestris are similar in terms of external morphology. Biology and Ecology

The adult flies from mid-June to mid-August (RÁKosY 2013). Males prefer Prunus spinosa and Scabiosa coumbaria, from where it can monitor its territory (EBert and RenNwald 1991, Hesselbarth et al. 1995).

Habitats are primarily on unfertilized calcareous grassland this includes chalk download, and undercliffs.

Distribution

The species occurs locally across Central Europe, Asia Minor and North Africa. It can be found from 0 to $1800 \mathrm{~m}$.

In Romania Thymelicus acteon can be found in almost every region, missing from Oltenia and Maramures (Fig. 4).

Conservation

The IUCN European status of Thymelicus acteon is least concern. The Romanian Red List status is near threatened. In Romania the worst threat is agriculture, pesticides and overgrazing (RÁkosy et al. in press).

\section{Thymelicus lineola (OCHSENHEIMER, 1808)}

\section{Diagnosis}

The color of the top of the wings varies from dark brown to orange-yellow. Both the edges and outer ribs of the wings are dark brown to black. There is a relationship between altitude and color intensification of ribs: the higher the altitude - the darker the margins and the ribs. Thymelicus lineola has morphological similarities with $T$. sylvestris, except the color of the lower part of the distal end of the antennas. In $T$. sylvestris it is brown to orange, while at $T$. lineola the end is black.

Biology and Ecology

Thymelicus lineola shares the same habitat with $T$. sylvestris. They both prefer areas rich in flowers such as meadows and grassy forest openings.

Adults fly from June to August (RÁkosy 2013). Depending on the altitude it can have one or two broods of offspring per year.

Distribution

Thymelicus lineola is a holarctic species (KUDRNA et al. 2011). It can be found as high as $2200 \mathrm{~m}$. It is found from southern Scandinavia through Europe to North Africa and from eastern to Central Asia.

In Romania it is found in all the historical regions (Fig. 5).

Conservation

In Romania its status of conservation is least concern as in all the EU countries (VAN SwAAY et al. 2014, RÁKosy et al. in press).

\section{Thymelicus sylvestris (PODA, 1761)}

\section{Biology and Ecology}

The habitat distribution is wide but it prefers sunny cliffs, meadows and grassy forest openings that are little fertilized.

Adults fly from June to August (RÁKosy 2013). The preferred food plants are Hypericum perforatum, Geranium robertianum, Inula hirta, Vicia faba, Viola tricolor, Salvia nemerosa.

Distribution

This butterfly's range includes much of Europe (east to the Urals, including Ireland, Britain and Scandinavia), north Africa and the Middle East. It typically occurrs where grass has grown tall. In Romania it is found in every region but missing from the southern part (Fig. 6). It prefers high altitudes $(1500 \mathrm{~m})$.

Conservation

In Romania its status of conservation is least concern as in all the EU countries (VAN SWAAY et al. 2014, RÁKOSY et al. in press).

\section{Hesperia comma (LinNAEUs, 1758)}

\section{Biology and Ecology}

It prefers warm calcareous sites, rich in Festuca ovina. Adults prefer Leucanthemum vulgare, Galium verum, Thymus serpyllum, Thymus comosus, Viola tricolor, Mentha, longifolia, Lotus corniculatus (EBERT and RENNWALD 1991, LAFRANCHIS et al. 2015).

Distribution

Hesperia comma is a holarctic species (KUDRNA et al. 2015). It has a wide distribution as far south as North Africa, northwards throughout Europe to the Arctic and eastwards across Asia to China and Japan. It is found as high as $2300 \mathrm{~m}$ (Tolman et al. 2001).

In Romania it was found in Transylvania, Banat, Dobrogea and northern Moldova (Fig. 7). It is found 
as high as $1400 \mathrm{~m}$.

Conservation

In Romania its status of conservation is least concern as in all the EU countries (VAN SwaAY et al. 2014, RÁkosY et al. in press).

\section{Ochlodes sylvanus (ESPER, 1777)}

\section{Diagnosis}

Ochlodes sylvanus resembles morphologically with Hesperia comma. The main differences are the androconic spots, which are totally black and the faded yellow-brown spots on the upper side of the rear wings.

Biology and Ecology

Ochlodes sylvanus is a univoltine species, the adults fly from mid-May to August.

It can be found anywhere where wild grasses grow tall. It prefers hedgerows, woodland clearings and edges (RÁKosy 2013). The food plants listed are Hypericum perforatum, Aster amellus, Leucanthemum vulgare, Trifolium pratense, Trifolium repens, Genista sagitalis, Thymus sp., Sambucus nigra, Centaurium umbellatum, Sambucus racemosa, Telekia speciosa, Cirsium sp., Carduus sp. (RÁkosy 2013).

Distribution

This species occurs throughout Europe, in the East Palearctic ecozone (northern Asia, China and Japan) and in the Nearctic realm (KUDRNA et al. 2015).

In Romania it is found in all regions as high as 1600 m (Fig. 8).

Conservation

In Romania its status of conservation is least concern as in all the EU countries (VAN SwAAY et al. 2014, RÁKosy et al. in press).

\section{Erynnis tages (LINNAEUS, 1758)}

\section{Biology and Ecology}

It prefers a variety of habitats including chalk downland, woodland clearings, coastal dunes, railway lines and waste ground.

It has two broods of offspring per year. The adults fly from April to August (RÁkosy 2013).

The foodplants are Medicago lupulina, Melilothus officinalis, Trifolium campestre, Hypericum perforatum, Leucanthemum vulgare, Dianthus carthusianorum, Agrimonia eupatoria, Linaria vulgaris, Rorippa sylvestris, Bunias orientalis, Hesperis tristis, Cardamine pratensis, Cardaminopsis arenosa, Arabis turrita, Alyssum petraeum, Dianthus carthusianorum, Leucanthemum vulgare (EBERT and RENNWALD 1991, Hesselbarth et al. 1995, LAFRANCHIS et al. 2015).

Distribution

It is found from Europe across Asia Minor and Central Asia to the Amur region. In Romania it is found in every region, as high as $1600 \mathrm{~m}$ (fig. 9).

Conservation
In Romania its status of conservation is least concern as in all the EU countries (VAN SwaAY et al. 2014, RÁKosY et al. in press).

\section{Carcharodus alceae (ESPER, 1780)}

Biology and Ecology

These quite common butterflies prefer dry warm and stony areas, wasteland, warm ruderals and gardens. In Romania it has three or more generations (RÁKOSY 2013).

They get nectar from various herbaceous plants Ajuga reptans, Lamium purpureum, Vinca minor and on wet soil or excrements (RÁKosy 2013).

Distribution

This species can be found in most of southern and central Europe, in northern Africa (Morocco east to Tunisia and Libya), in the Middle East, in Asia Minor, the Caucasus, in northern India, in the Middle and Central Asia, in the western Himalayas and in the south of Western Siberia as high as $2000 \mathrm{~m}$.

In Romania it is found in Transylvania, Banat, Moldova, Dobrogea, northern Crișana region and in Maramureș as high as $1300 \mathrm{~m}$ (Fig. 10) (RÁKosY 2013).

Conservation

The IUCN European status of Carcharodus alceae is least concern. The Romanian Red List status is also least concern but the population is in slightly decline since 2000 due to agriculture and habitat loss (RÁKosY et al. in press).

\section{Carcharodus lavatherae (ESPER, 1783)}

Biology and Ecology

It is a xero- and xeromesophilic species. It prefers grasslands with Stachys sp. and limestone or claysandy soil. The ideal habitats are 2-3 years old lawns and rocky lawns, located at altitudes lower than 700 m (RÁKosy 2013). It is a univoltine species and flies from the end of May to the end of July.

Butterflies often sit on the ground or rocks, being excellent camouflaged. They extract mineral salts from wet soil, excrements or small animal corpses.

Distribution

It is found from the Rhine Rift Valley in central Germany up to North Africa and from south-eastern France up to Anatolia as high as $200-1600$ m (Tolman et al. 2001).

In Romania it is found in Transylvania, Carpathian Mountains, Clisura Dunării, Cheile Nerei and Valea Cernei at an elevation between $100-1300$ meters above sea level (RÁKosy 2013) (Fig. 11).

Conservation

The IUCN European status of Carcharodus lavatherae is least concern. In Romania it is near threatened due to habitat loss and overgrazing (RÁKosy 2013, RÁKosy et al. in press). 


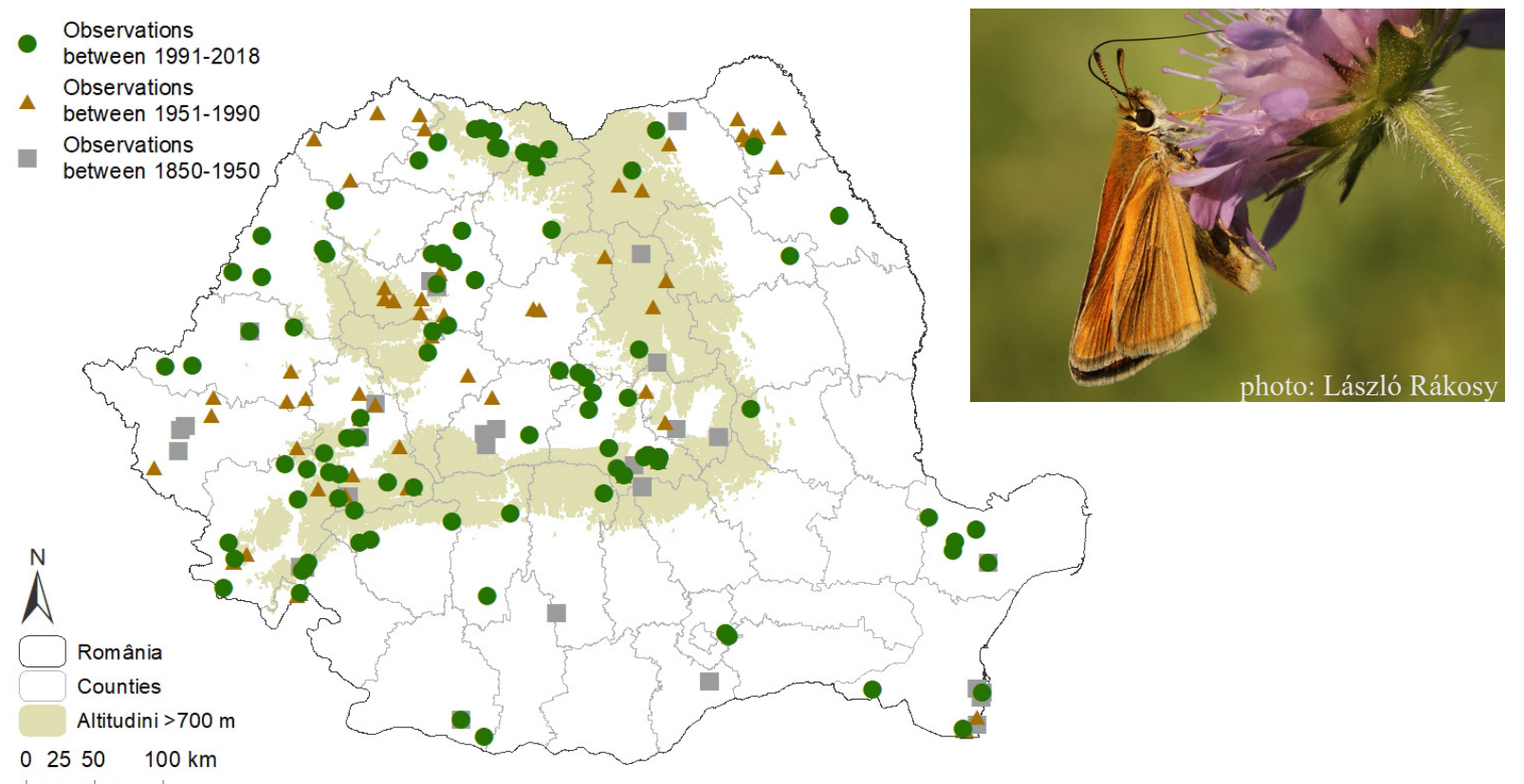

Fig. 5. Distribution map of Thymelicus lineola in Romania

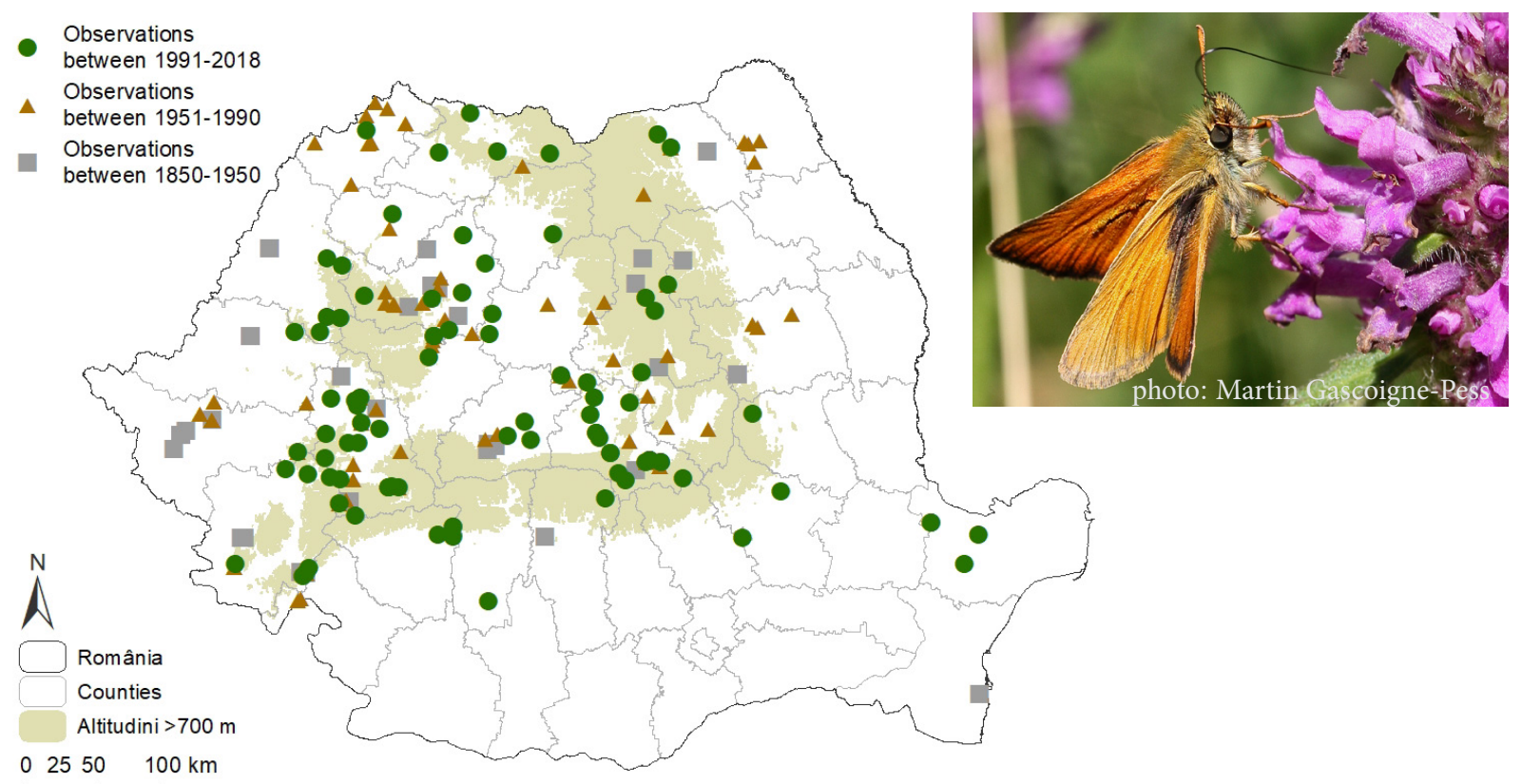

Fig. 6. Distribution map of Thymelicus sylvestris in Romania

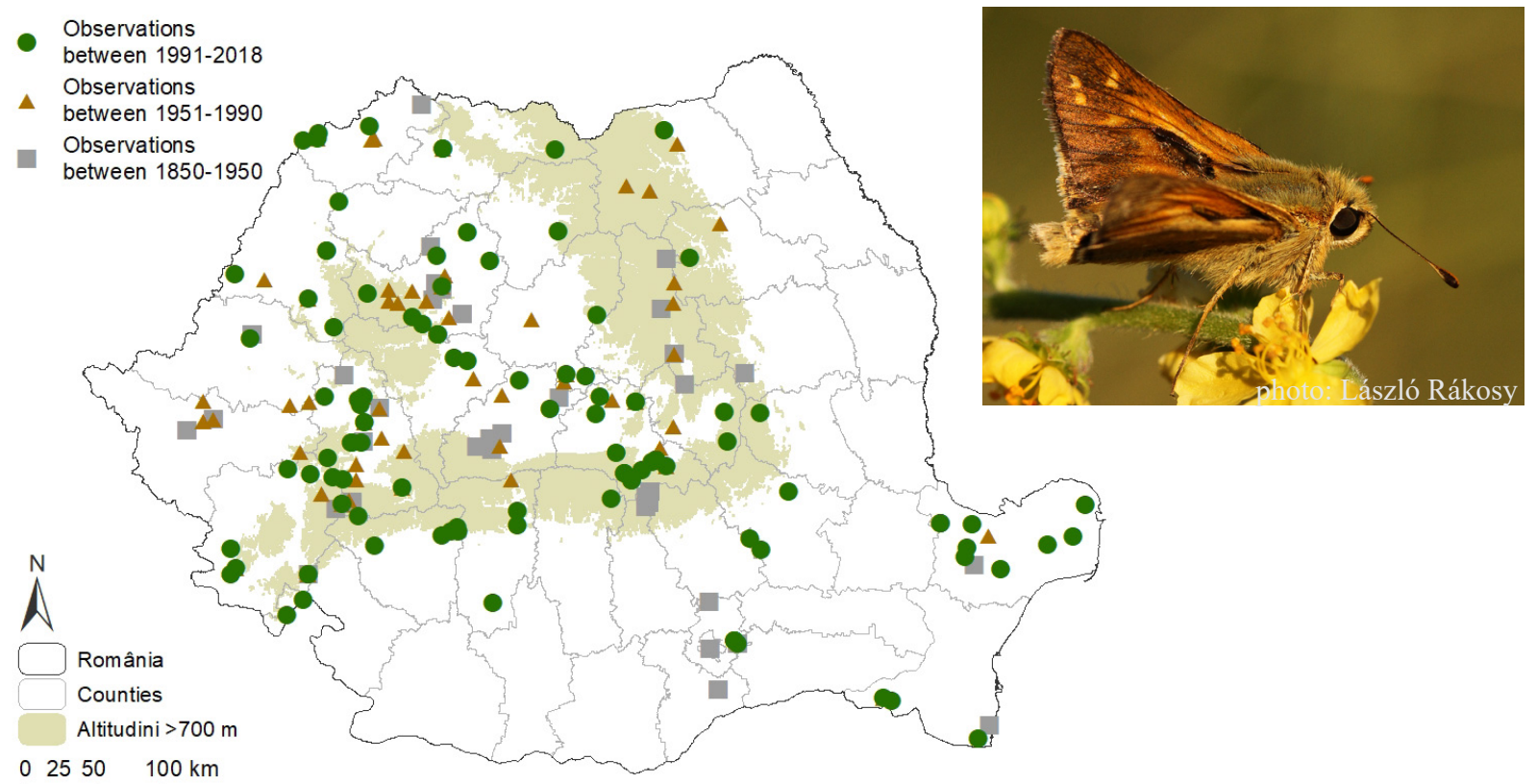

Fig. 7. Distribution map of Hesperia comma in Romania 
- Observations

between 1991-2018

Observations

between 1951-1990

- Observations

between 1850-1950
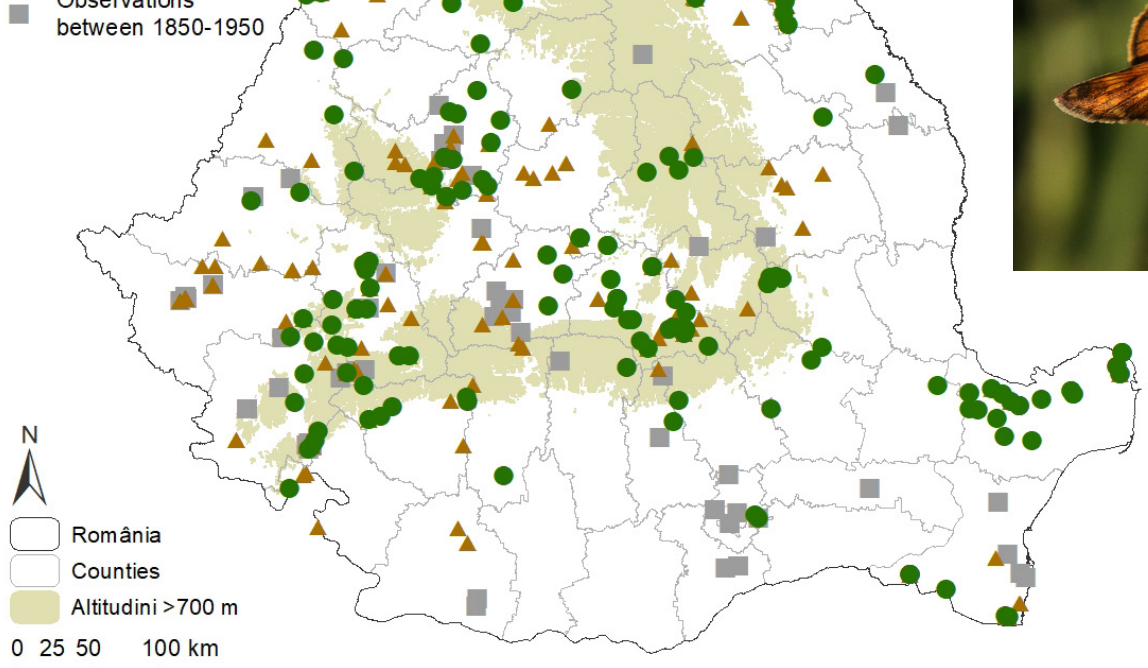

Fig. 8. Distribution map of Ochlodes sylvanus in Romania

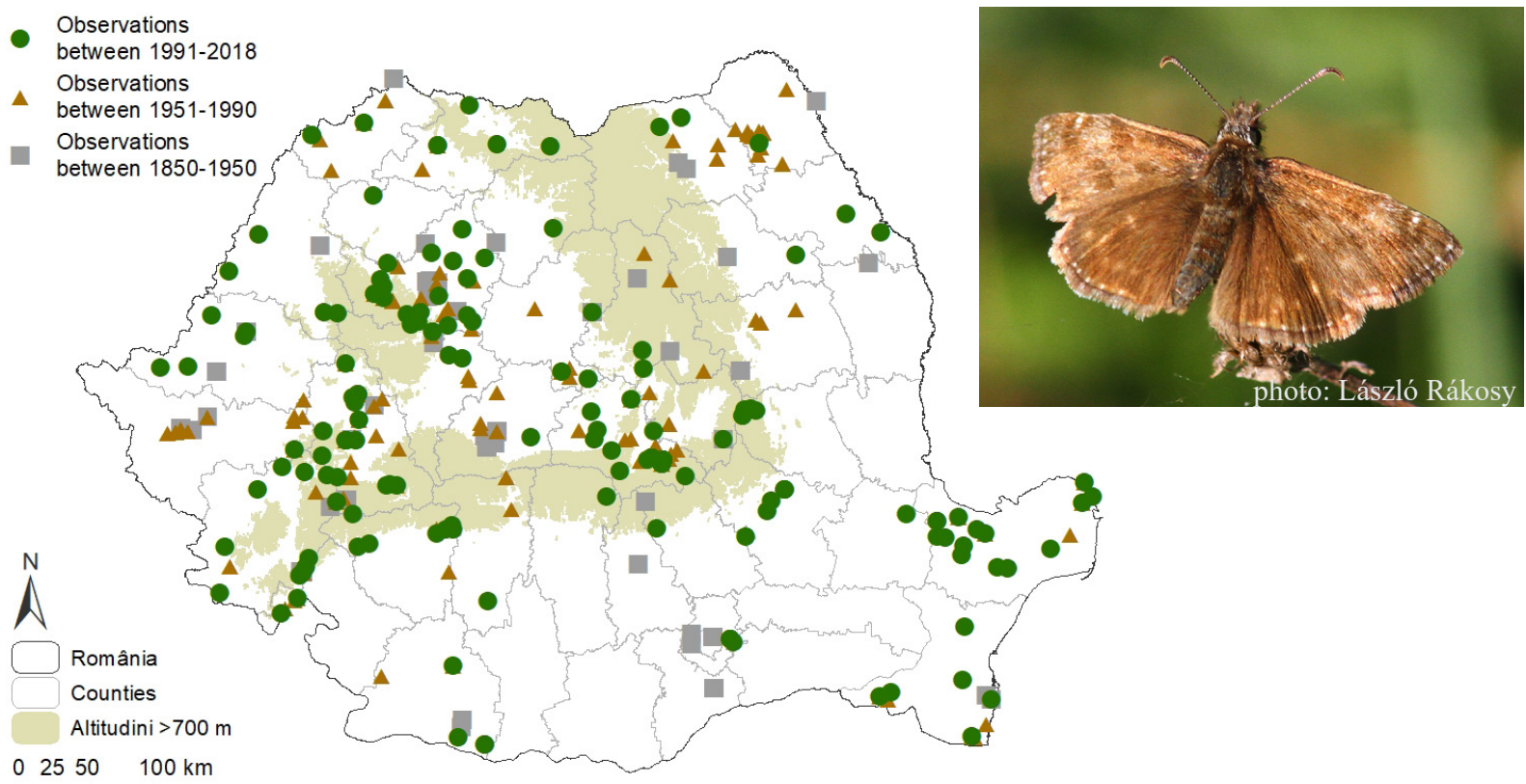

Fig. 9. Distribution map of Erynnis tages in Romania

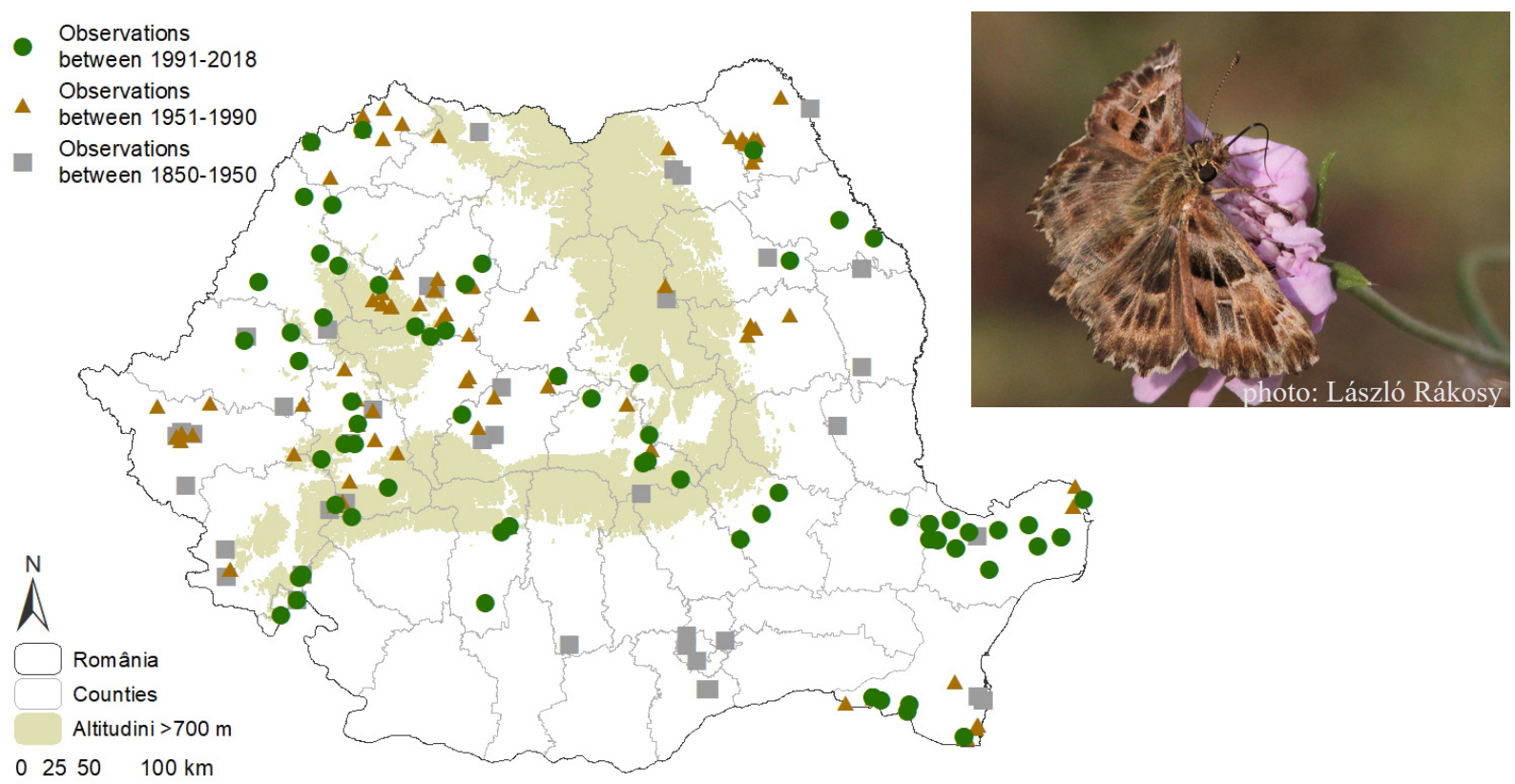

Fig. 10. Distribution map of Carcharodus alceae in Romania 


\section{Carcharodus flocciferus (ZELLER, 1847)}

\section{Diagnosis}

It is very similar to $C$. alceae - the color of the top of the wings is dark-brown, the six white spots well contrasted on the front wings. It is distinguished by the presence of three white spots on the posterior wings, narrower than those of $C$. lavatherae (SETTELE et al. 2015). The dimension of the upper wing resembles C. orientalis (Tolman et al. 2001). It is advisable to study the genital armature to confirm the accuracy of the diagnosis.

\section{Biology and Ecology}

The species is common in wet habitats, such as flooded meadows, which dry out during summer, and in mesophilic or xero-thermophilic habitats, for example steppe meadows on limestone cliffs. It is a univoltine species found as high as $800 \mathrm{~m}$ and bivoltine in plain and hilly regions (RÁKosy 2013).

Adults fly from May to June or July to August in two generations. It feeds on Linum flavum, Lamium album, Origanum vulgare, Malva officinale etc.

Distribution

This species can be found in the Mediterranean region, the Alps and the Balkans, from southern and central Europe. In Romania it is found in all the historical regions (Fig. 12).

\section{Conservation}

The IUCN European status of Carcharodus flocciferus is least concern. In Romania it is near threatened and vulnerable due to overgrazing and habitat loss (RÁKosY et al. in press).

\section{Carcharodus orientalis (REVERDIN, 1913)}

\section{Biology and Ecology}

Carcharodus orientalis prefers habitats such as limestone-steppe meadows, bushes, and anthropogenic habitats - ditches and road edges, abandoned quarries (RÁkosy 2013). It is bivoltine in Dobrogea, the first-generation flies from mid-May to July and the second-generation flies from July to the end of September (RÁKosY and VARGa 2000).

Distribution

The species has a Balkan Pontic-Caspian distribution (Hesselbarth et al. 1995, Tuzov 1997, Rákosy and VARGA 2000). It is also found in northern Iran as high as $1650 \mathrm{~m}$ (Tolman et al. 2001).

In Romania it is found in Dobrogea and North Moldova as high as $450 \mathrm{~m}$ (Fig. 13).

Conservation

The IUCN European status of Carcharodus orientalis is least concern. In Romania this species has a status of least concern - near threatened because of overgrazing and habitat loss (RÁKosY et al. in press).

\section{Spialia orbifer (HÜBNER, 1823)}

Biology and Ecology

Adults are on wing from April to August in one or two generations per year.

The habitat consists of steppe on plains and grassy slopes (RÁKosY 2013).

Adults feed on nectar from flowers such as Lotus corniculatus, Centaurea sp., Scabiosa sp. (EBERT and RenNwald 1991, Hesselbarth et al. 1995).

\section{Distribution}

It is found from south-eastern Europe and temperate Asia to Korea. In Romania it is found in Dobrogea, the Southern Carpathians, the Curvature Carpathians and Izvorul Mureșului. Surprisingly, this species has not been reported in Transylvania. In Romania it is found as high as $900 \mathrm{~m}$ (Fig. 14).

Conservation

The IUCN European status of Spialia orbifer is least concern. In Romania its status is least concern - near threatened (VAN SwAAY et al. 2014, RÁKOSY et al. in press).

\section{Muschampia cribrellum (EVERSMANN, 1841)}

\section{Diagnosis}

The species is much like $M$. tessellum. It is distinguished by the stronger contrast of white spots on the brown or dark-gray side of the ventral and dorsal side of the wings through the 5 spots in the lower subapex region of the anterior wings (2:1:2 in M. cribrellum, 2: 0: 2 to $M$. tessellum) and the group of 4-5 spots in the upper postal region of all previous wings (M. tessellum has 3) (RÁKosy 2013). The genital armature is recommended for correct diagnosis.

Biology and Ecology

Adults fly from May to June. The species has only one generation per year. It is a species of dry grasses.

\section{Distribution}

It is a Euro-Siberian species, found from southeastern Europe, the Caucasian region, southern Siberia, southern Ural Mountains, Kazakhstan, Altai, Mongolia, Amur region, North and West of China (RÁKosy 2013, Tolman et al. 2001).

There are known populations in Cluj, Sălaj, Mureş, Harghita, Hunedoara. In Romania it is found as high as $100-800 \mathrm{~m}$ (Fig. 15).

Conservation

The IUCN European status of Muschampia cribrellum is near threatened all over Europe (VAN SwAAY et al. 2010). In Romania the species is classified as endangered and is protected by law since 2005 (VAN SWAAY et al. 2014, RáKosY et al. in press).

\section{Muschampia tessellum (HÜBNER, 1803)}

Biology and Ecology

It is a xero-thermophilic species and it has ecological preferences similar to M. cribrellum. It is found in steppe meadows on limestone or clay-sandy soil, grasslands with high vegetation, hedges, as well as in overburdened or slightly ruderalized habitats (RÁKOSY 2013). In Romania (Transylvania) it is bivoltine and it flies from middle of May until the end of June 
- Observations

between 1991-2018

Observations

$\Delta$ between 1951-1990

Observations

between $1850-1950$
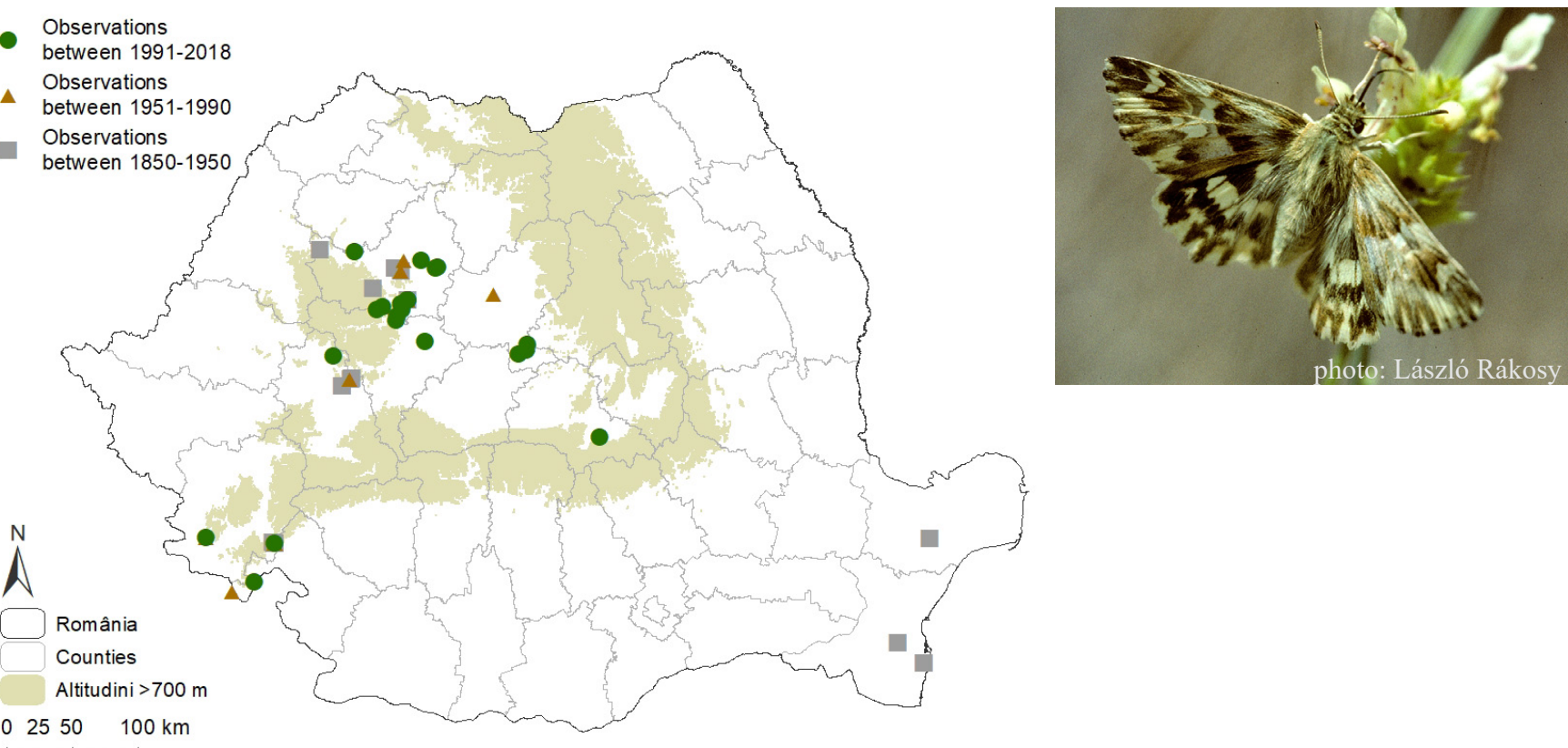

Fig. 11. Distribution map of Carcharodus lavatherae in Romania

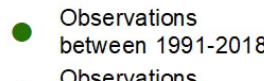

Observations

between 1951-1990

- Observations

between 1850-1950
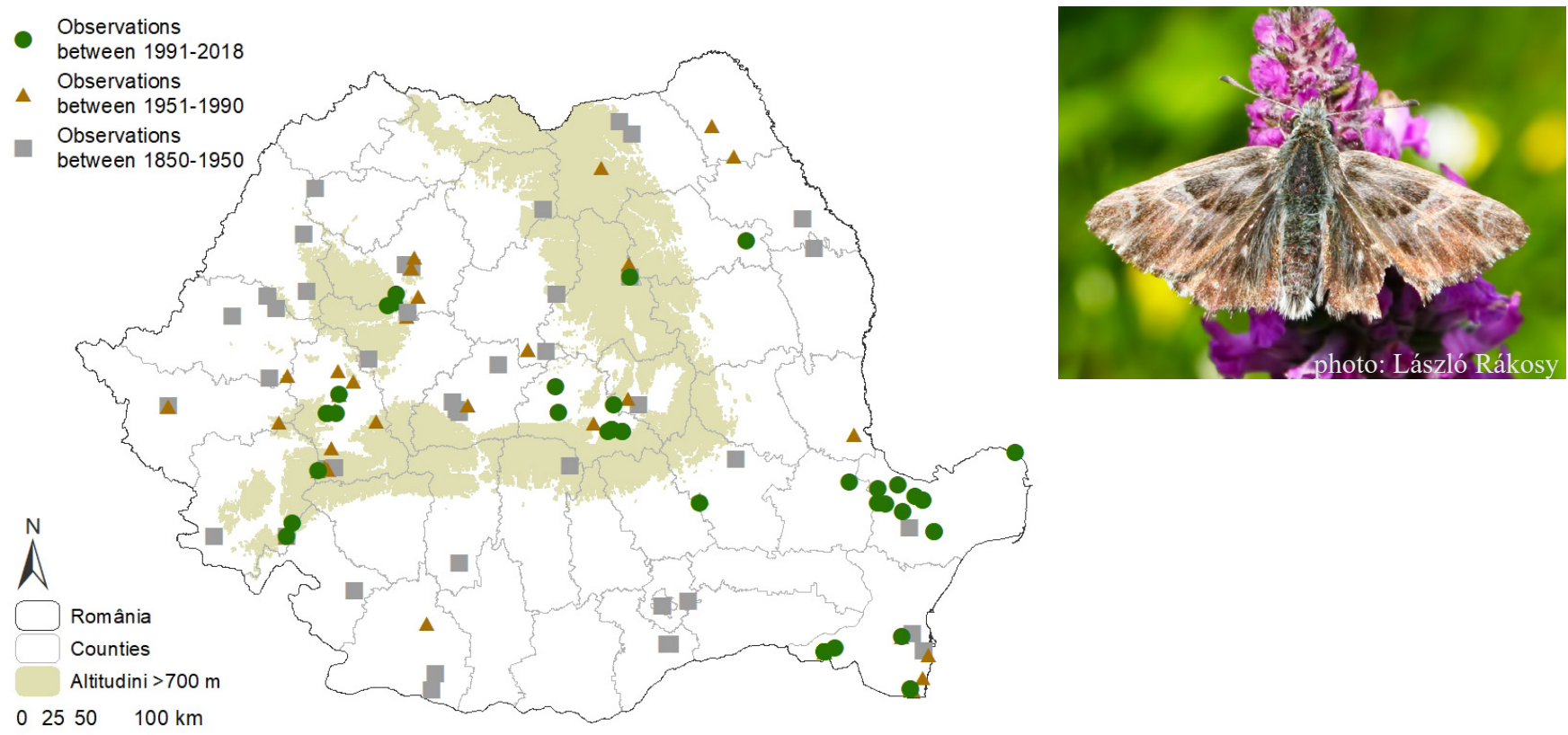

Fig. 12. Distribution map of Carcharodus flocciferus in Romania
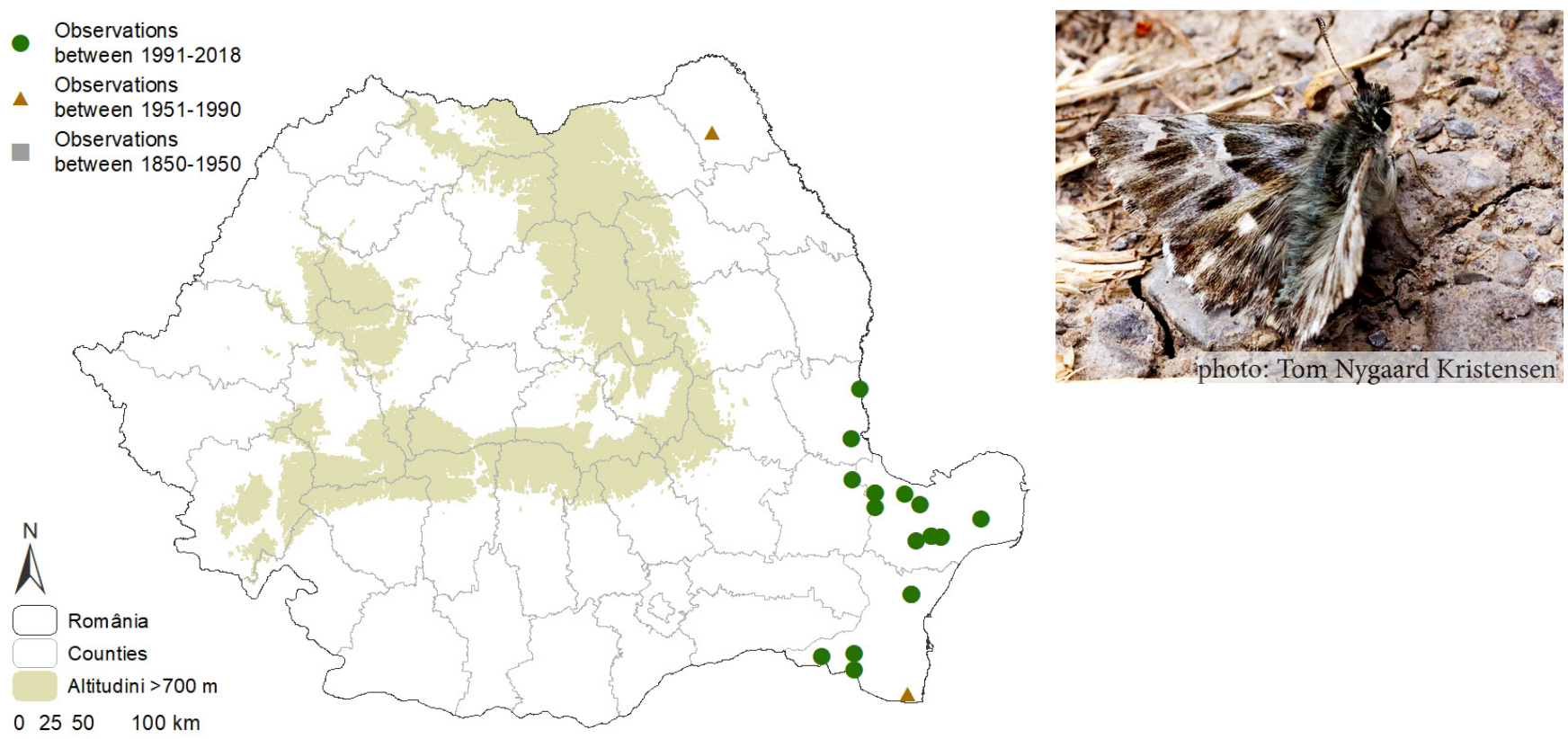

Fig. 13. Distribution map of Carcharodus orientalis in Romania 


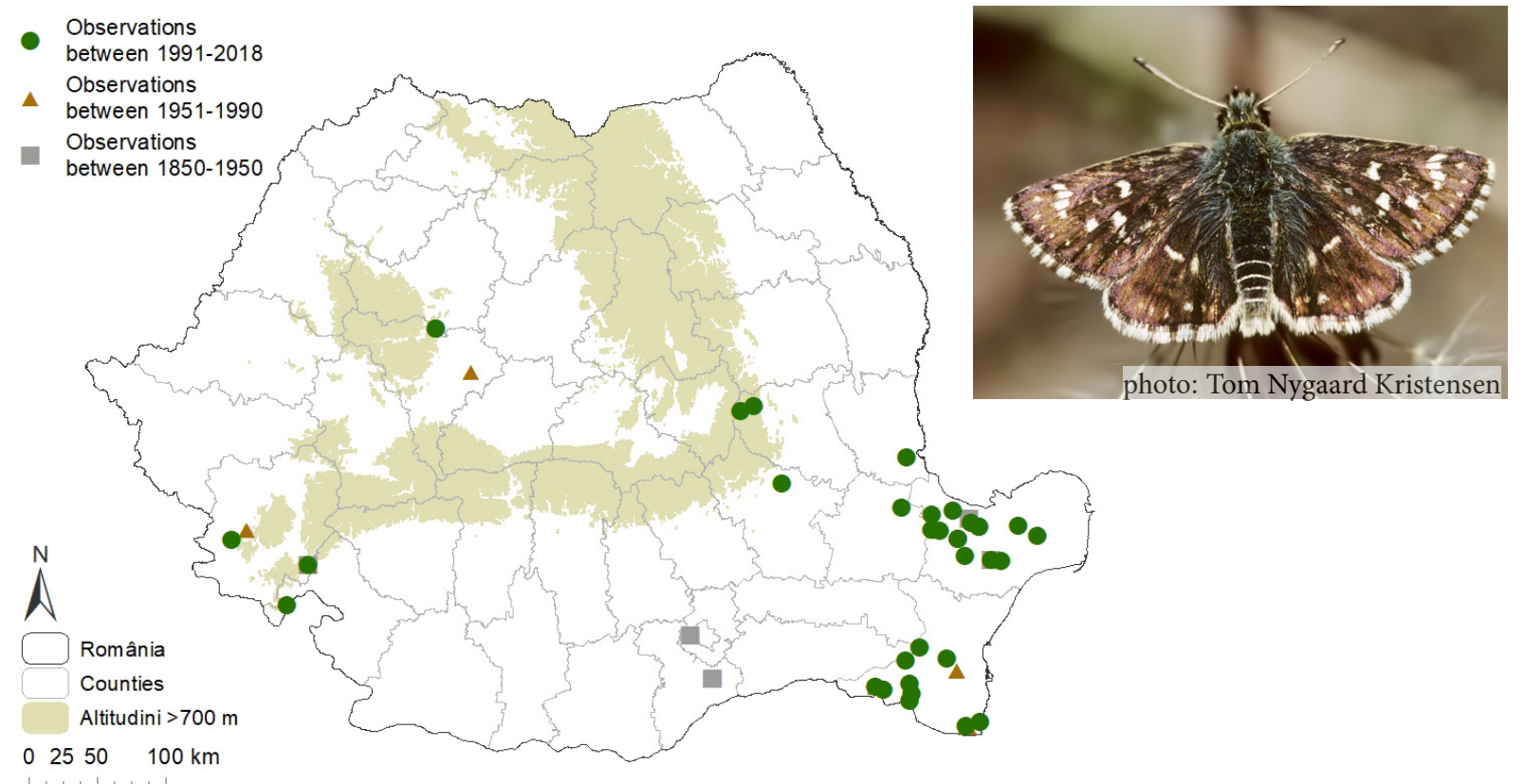

Fig. 14. Distribution map of Spialia orbifer in Romania

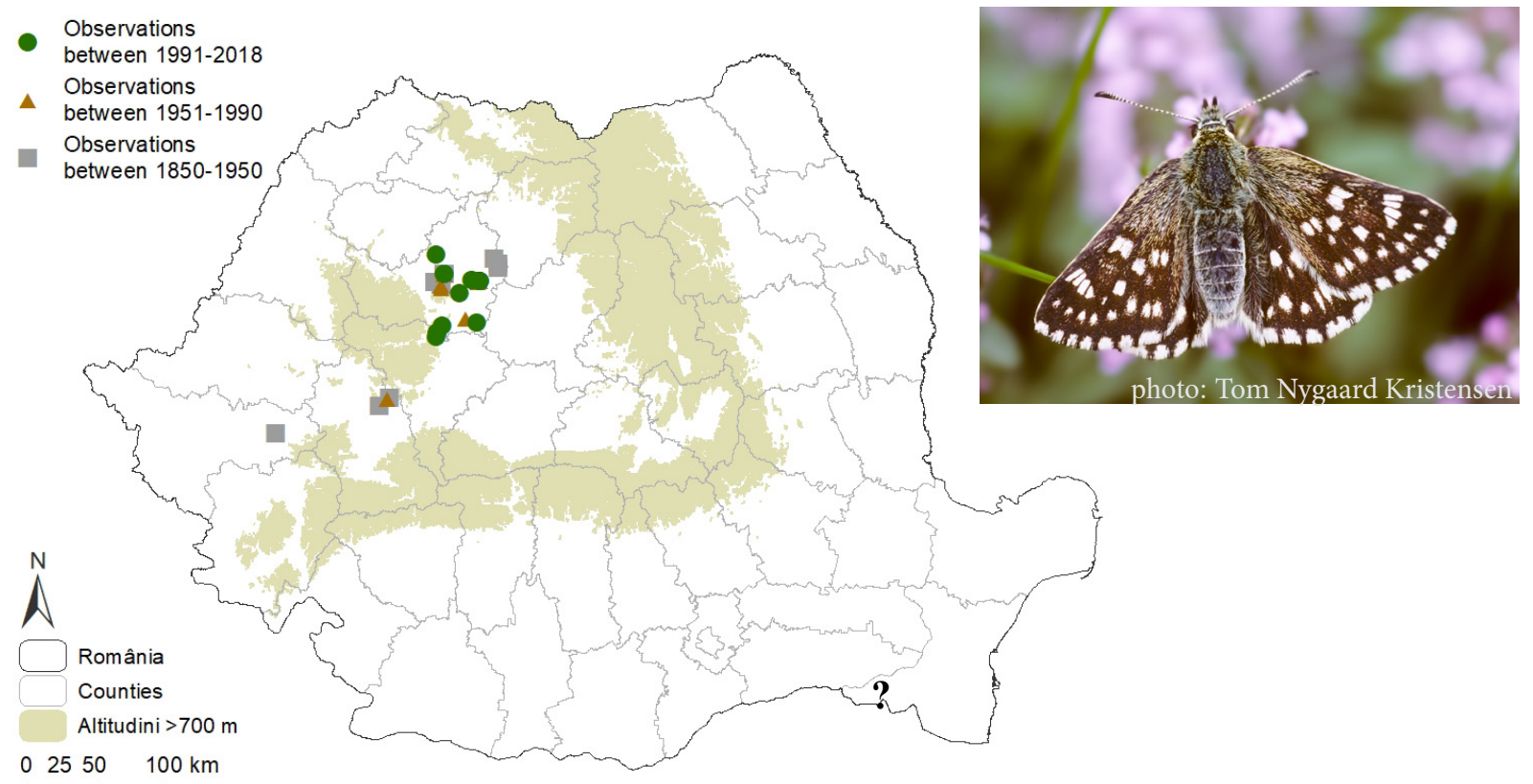

Fig. 15. Distribution map of Muschampia cribrellum in Romania

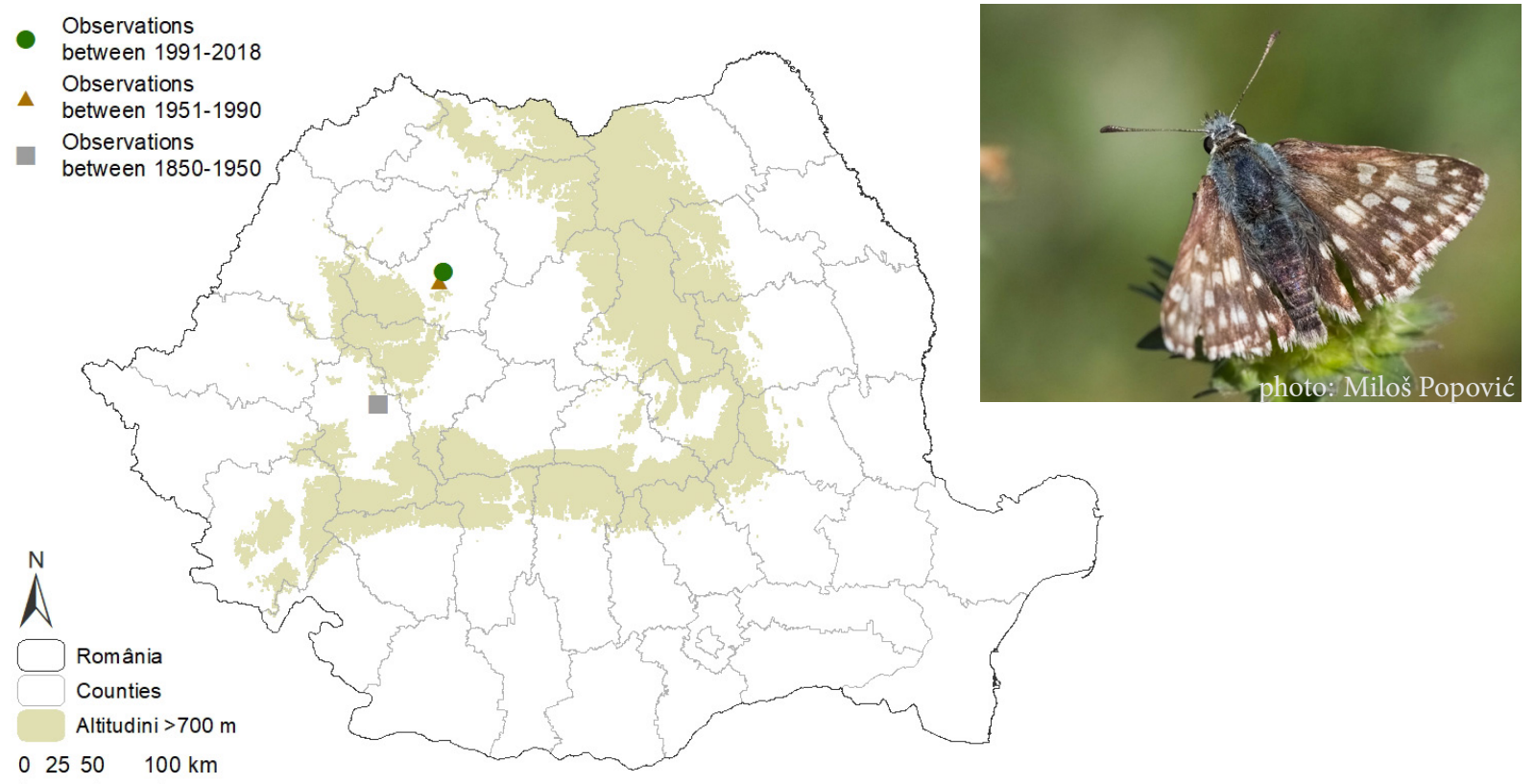

Fig. 16. Distribution map of Muschampia tessellum in Romania 
and from the end of July to August (RÁKosy 2013; RÁKosy and GoIA 1997). In the rest of the area, the species is univoltine and flies from mid-May to midAugust (Tolman et al. 2001). Males have territorial behavior. In Transylvania larvae live on Phlomis tuberosa (RÁkosY 2013). Adults feed preferentially with nectar of Thymus sp., Vicia sp., Phlomis sp. and Achillea millefolium (VAn SWAaY et al. 2014).

Distribution

It is found from the southern Balkan Peninsula (Macedonia, Bulgaria, Greece and the European part of Turkey) through Ukraine and Asia Minor, southern Siberia, Mongolia, east to the Amur region (Tolman et al. 2001, VAN SWAAY et al. 2010). In Romania the species was reported only in Transylvania, Săcărâmb and Fânaţele Clujului. It is found between 350 and 650 meters. The recording of the species from Săcărâmb is very old (Fuss 1850). The only population with recent reports is known from Fânaţele Clujului (Fig. 16). Unfortunately, the population from Fânaţele Clujului is extremely scarce, the species being threatened with extinction.

\section{Conservation}

The IUCN European classified the species as LC and it is not considered necessary to take protective and conservation measures (VAN SWAAY et al. 2014). In Romania the populations are very small and isolated, resting in the Transylvanian region, and have led to the classification of the taxon as critically endangered (RÁkosy et al. in press).

\section{Pyrgus malvae (Linnaeus, 1758)}

\section{Diagnosis}

With its characteristic chequered black-and-white pattern, the grizzled skipper is quite distinctive. It is small, with an average wingspread of 12 millimeters. On the ventral side of the posterior wings, the ribs are evident due to the color of the white to creamy color, and the spots are white. The lower part of the distal end of the antennas is dark brown. It is the smallest butterfly in the Pyrgus genus in Romania (Pro Natura 2000).

Biology and Ecology

Pyrgus malvae is a meso-xerophilic species with a wide range of habitats, including ruderal. It can be found in any type of meadows, but they prefer those with a mosaic structure, limestone or sandy soil, abundant in flowers and airy vegetation (RÁKosy 2013). It is bivoltine up to $700 \mathrm{~m}$ and univoltine up to over 1500 $\mathrm{m}$ altitude. Adults fly from mid-April to late June and from July to mid-September (RÁKosy 2013). Adults were seen on Salvia nemorosa, Leucanthem vulgis, Hypericum perforatum, Senecio vulgaris, Galium verum, Solidago virgaurea, Potentilla reptans, Silene vulgaris, Cardamine pratensis, Hesperis tristis, Cardaminopsis arenosa, Alyssum alyssoides, Fragaria vesca, but also on animal excrement and moist soil (EBERT and RENNWALD 1991, LAFRANCHIS et al. 2015).

Distribution

Pyrgus malvae has a eurasiatic distribution (KUDRNA et al. 2011). It is found as high as $1600 \mathrm{~m}$. It occurs in Europe, northwestern Turkey, Mongolia, northern China and Korea, in southern and south-west France, southern Switzerland as well as in Italy (ToLmaN et al. 2001, RÁkosy 2013). In Romania it is found in all the historical regions (Fig. 17).

Conservation

In Romania its status of conservation is least concern as in all the EU countries (VAN SWAAY et al. 2014, RÁkosY et al. in press).

\section{Pyrgus armoricanus (OBERTHÜR, 1910)}

\section{Diagnosis}

Like all Pyrgus species, it can be very difficult to identify in the field. The upper side of the forewings are often noticeably darker brown than other Pyrgus species, especially when fresh, with clear white markings. It resembles other grizzled skipper $(P$. alveus). It is slightly bigger than Pyrgus malvae. This species is quite similar to Pyrgus carthami, Pyrgus alveus, Pyrgus serratulae and Pyrgus malvae.

Biology and Ecology

They are found in wet habitats with southern exposure (peatlands, marshlands). However, they prefer grasslands with low vegetation, vegetationcovered rocks and pastures in the hilly-mountainous area (RÁKosy 2013). Males have a territorial behavior (EBERT and RENNWALD 1991). They are bivoltine and fly from mid-May to late June and from August to late September (RÁKOSY 2013).

Distribution

It has a west Palearctic distribution (KUDRNa et al. 2011). It is found in northern Africa, Europe, Turkey, the Transcaucasian, Northwest Asia and Southern Ural.

In Romania it is found in Dobrogea, Carpathians, Transylvania, Banat, Maramureș, Bucovina and Moldova as high as $1450 \mathrm{~m}$ (Fig. 18).

Conservation

In Romania its status of conservation is least concern as in all the EU countries (VAN SwAAY et al. 2014, RÁkosY et al. in press).

\section{Pyrgus alveus (HÜBNER, 1803)}

\section{Diagnosis}

It has a wingspan of 22-32 $\mathrm{mm}$. The dorsal side of the wings is grayish-brown with small, faded white spots. The ventral side of the posterior fingers is yellowishgreen, with large discs, joined together and forming stripes (Tuzov 1997). The lower part of the distal end of the antenna is light-reddish-brown (RÁKOSY 2013). It can be easily confused with the safflower skipper (Pyrgus carthami) as the two species are often found in similar habitats. Pyrgus carthami can usually be 
distinguished from Pyrgus alveus by its more closely grouped white spots on the forewing and a band of evenly sized pale spots in the postdiscal area of the hindwing. It is advisable to study the genital armature to confirm the accuracy of the diagnosis.

Biology and Ecology

It is a meso-thermophilic species, present in many types of meadows, but preferably in extensive pastures, mountain and subalpine meadows, as well as meadows to the upper boundary of the forest (RÁkosy 2013). It is a univoltine species and flies from the beginning of June until the end of August. Adults have a fast flight and can be observed on wet soil, where they extract mineral salts (VAN SWAAY et al. 2014).

Distribution

P. alveus has a palearctic distribution (KUDRNA et al. 2011). It is found from North Africa, Europe, Turkey, Asia Minor, Caucasus Mountains, Southern and Western Siberia, Urals, Central Asia, Mongolia and North China (Tolman et al. 2001).

In Romania it is found in Banat, Carpathians, Transylvania and Moldova between 200 and $1800 \mathrm{~m}$.

(Fig. 19) (RÁkosy 2013).

Conservation

The IUCN European Red List status of Pyrgus alveus is least concern. The Romanian Red List status is also least concern/ near threatened (VAN SWAAY et al. 2014, RÁKosY et al. in press).

\section{Pyrgus serratulae (RAMBUR, 1840)}

\section{Biology and Ecology}

This is a relatively distinctive species; the upper side has tiny white marks on the forewings and almost unmarked on the hindwings. The underside is usually mostly olive-green with faded markings. The wingspan is $24-32 \mathrm{~mm}$. It habits many types of meadows, but they prefer those rich in flowers, meso-xerophilic on limestone or sandy-clay soil in the hilly-mountainous area. It is a univoltine species, flying according to the altitude where it is found: in Dobrogea in April-May, in the hilly area from mid-May to the end of June and in the mountain-subalpine area in July-beginning of August. Butterflies have been observed on wet soil and excrements, where they extract mineral salts (RÁkosy 2013).

Distribution

It has a Eurasian distribution (KUDRNA et al. 2011). It is found in Spain, from Central Europe to Asia Minor, Iran, Libyan, South and Central Siberia, Mongolia and North East China (Tolman et al. 2001, Tuzov 1997).

In Romania the species was reported in Dobrogea, Southern Carpathians and Curvature Carpathians, Transylvania and northern Moldova. It is found between 50 and $400 \mathrm{~m}$ (Fig. 20).

Conservation

The IUCN European Red List status of Pyrgus serratulae is least concern. The Romanian Red List status is data deficient (VAN SWAaY et al. 2014, RÁKosY et al. in press).

\section{Pyrgus carthami (HÜBNER, 1813)}

\section{Diagnosis}

With a wingspan of $30-34 \mathrm{~mm}, P$. carthami is the largest species of Pyrgus. It distinguishes itself from other species by the presence of a white-gray "heap" on the edge of the ventral faces of the wings (RÁKOSY 2013). On the dorsal side of the posterior wings there is a series of small white spots in the submarginal region, which in some individuals continue on the previous wings, but are more faded (TOLMAN et al. 2001). The lower part of the distal end of the antennas is dark brown. It can be confused with Pyrgus alveus as the two species are often found in similar habitats. It is advisable to study the genital armature to confirm the accuracy of the diagnosis.

Biology and Ecology

It habits meadows on a limestone substrate, claysandy or loess with nude ground portions and short vegetation, weakly tucked up with many individuals of Bromus sp. and Festuca sp. It is a univoltine species and flies from mid-May to August. Flight times may vary, depending on microclimate and altitude (RÁKosy 2013). Adults were observed on Trifolium pratense, Trifolium campestre, Leucanthemum vulgare, Hieracium pilosella, Agrimonia eupatoria, Medicago lupulina, Anthyllis vulneraria, Galega officinalis, Linum flavum, Solidago virgaurea.

\section{Distribution}

It is a Eurasian species (KudRna et al. 2011) and it is found from southern Europe to Asia Minor and western Siberia (Tuzov 1997, Tolman et al. 2001).

In Romania it is found in Transylvania, Carpathians and northern Moldova between 100 and 1500 m (Fig. 21).

\section{Conservation}

In Romania its status of conservation is least concern as in all the EU countries (VAN SWAAY et al. 2014, RÁKosY et al. in press).

\section{Pyrgus andromedae (WALlEngRen, 1853)}

\section{Diagnosis}

It resembles $P$. cacalie, but can be distinguished by morphological characters or by studying the genital armature to confirm the accuracy of the diagnosis. $P$. andromedae has three white spots in the basal region of the ventral side of the posterior wings ( $P$. cacalie has only two, the middle one is missing). Also, the white spot is more or less faded (but always present) in the disc, dorsal area of the posterior wings, which is elongated in this species (DINCĂ et al. 2008). It is advisable to study the genital armature for a correct diagnosis.

Biology and Ecology 
- Observations

between 1991-2018

Observations

between 1951-1990

- Observations

between $1850-1950$

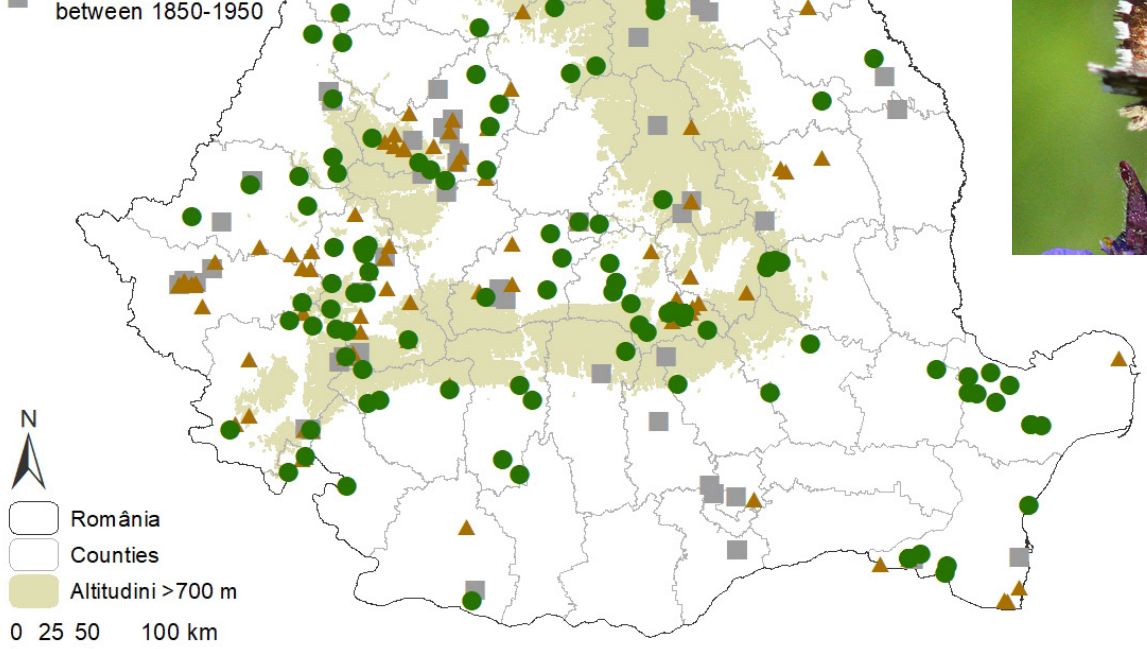

Fig. 17. Distribution map of Pyrgus malvae in Romania

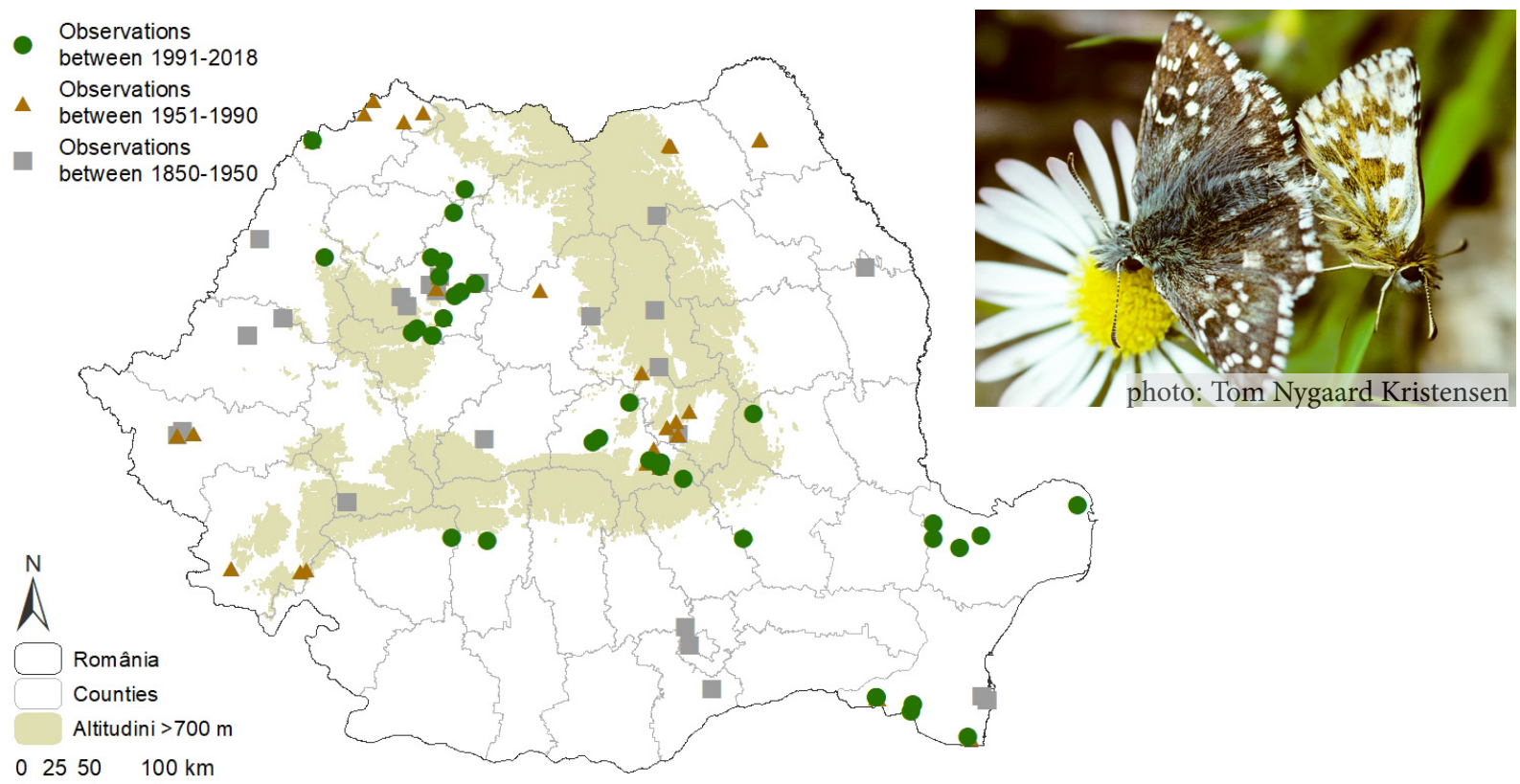

Fig. 18. Distribution map of Pyrgus armoricanus in Romania

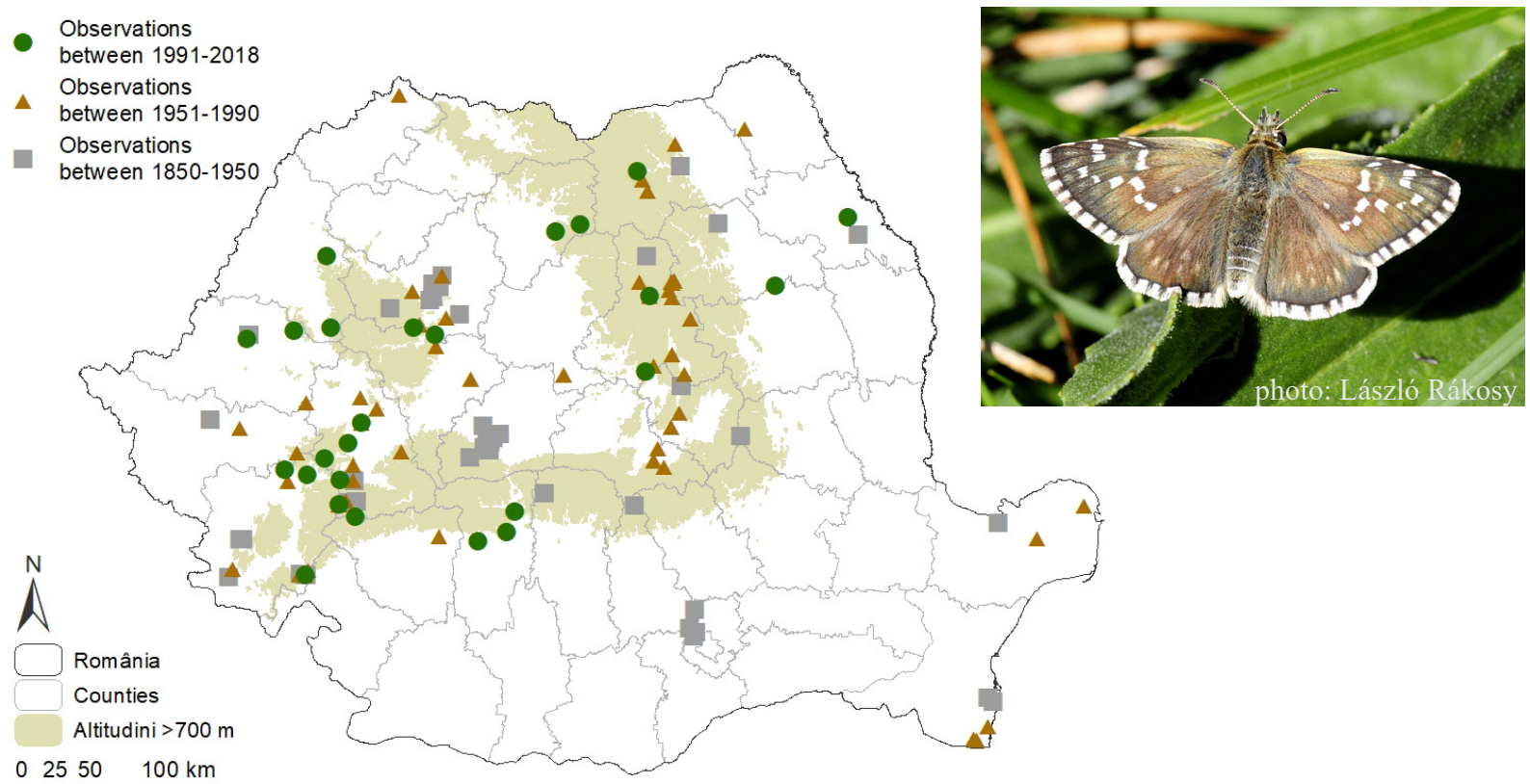

Fig. 19. Distribution map of Pyrgus alveus in Romania 


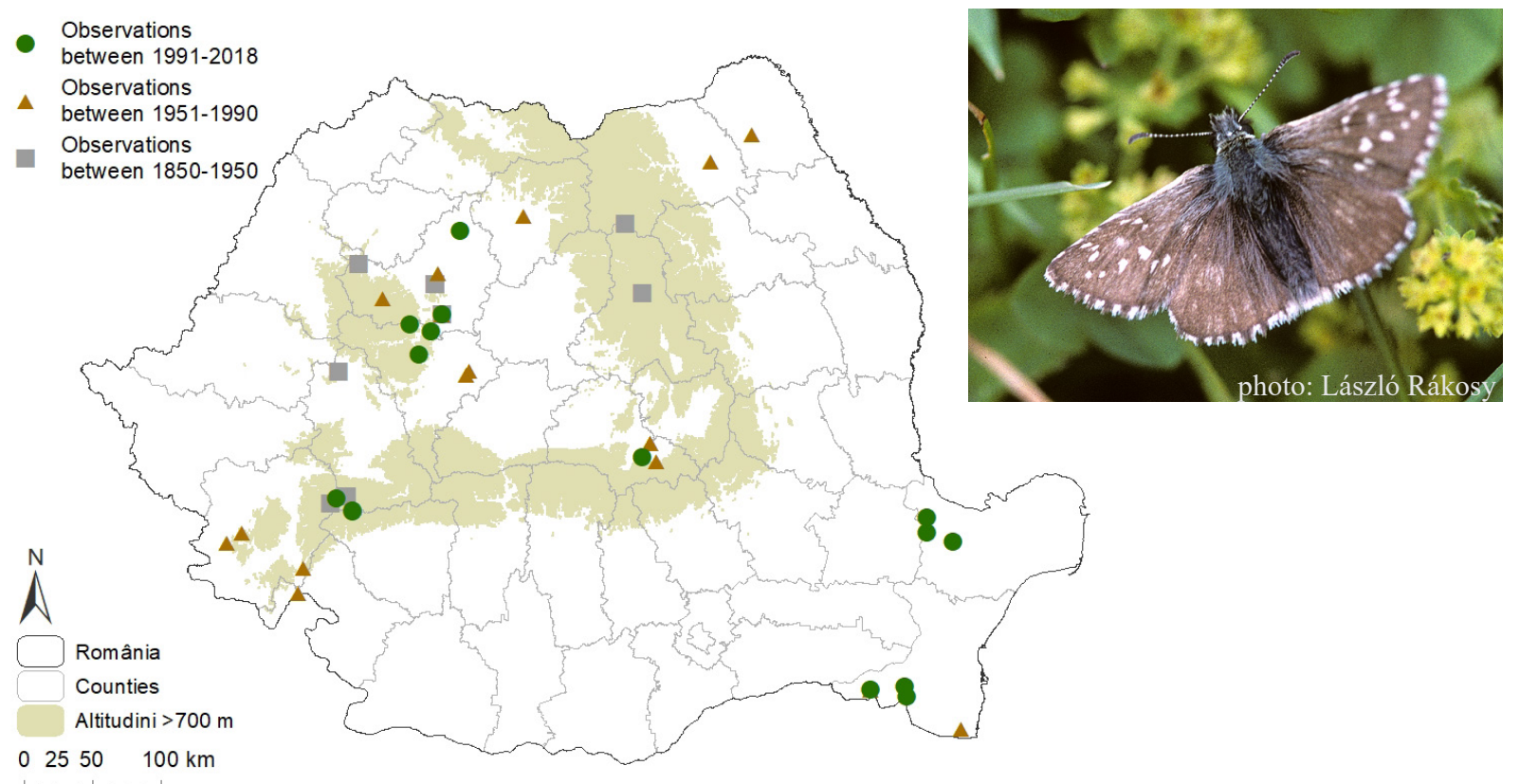

Fig. 20. Distribution map of Pyrgus serratulae in Romania

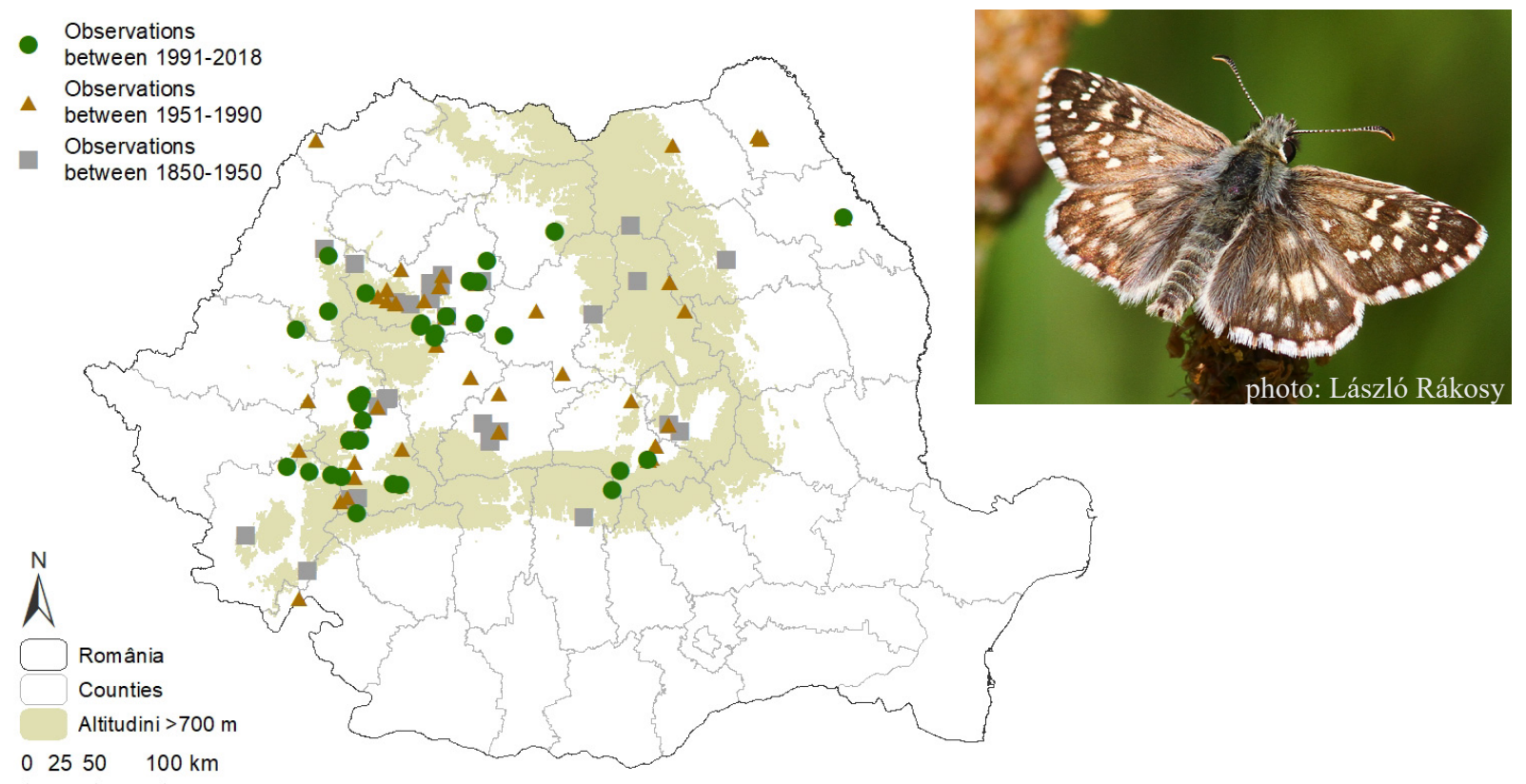

Fig. 21. Distribution map of Pyrgus carthami in Romania

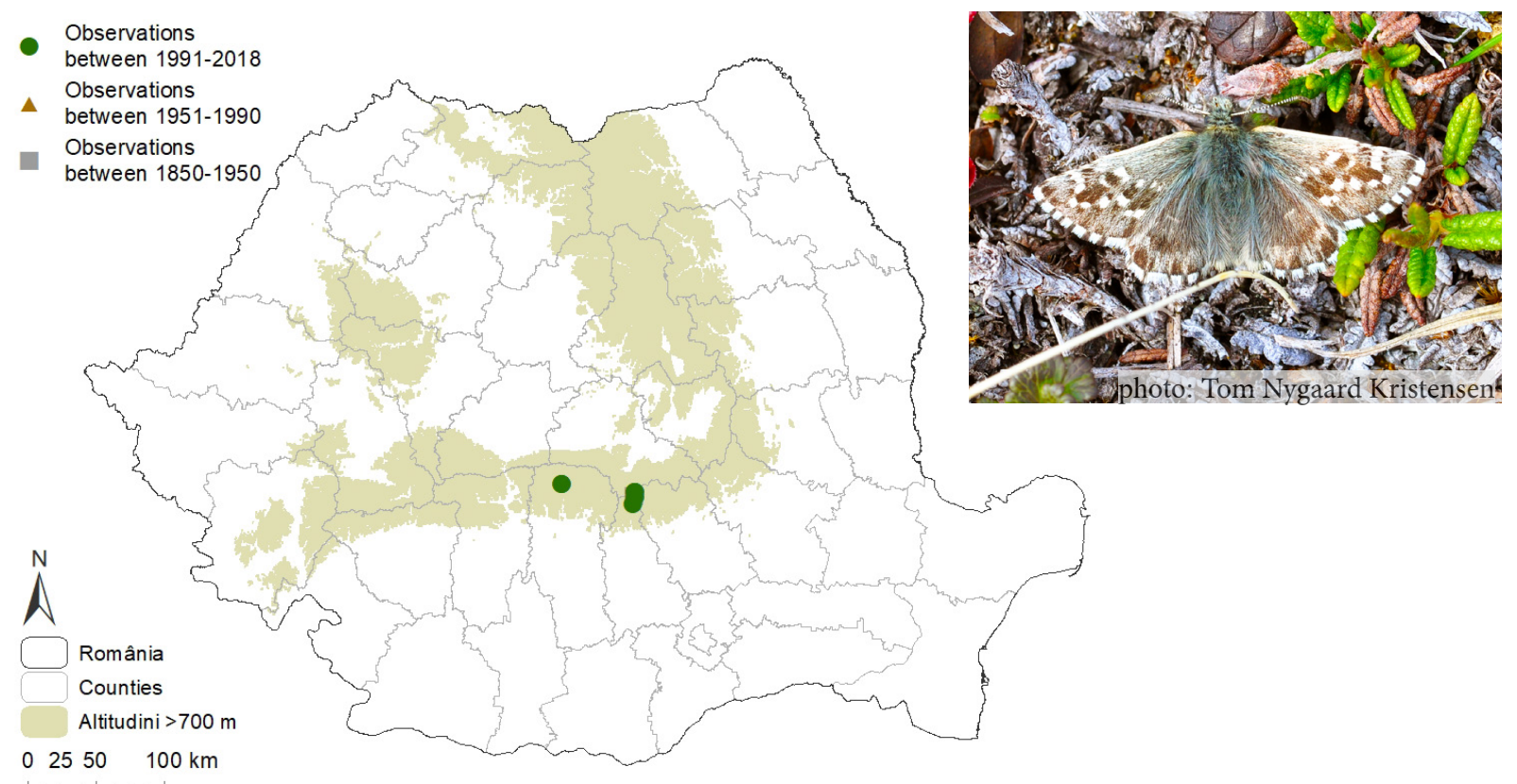

Fig. 22. Distribution map of Pyrgus andromedae in Romania 
It is found in subalpine and alpine meadows as high as $1500 \mathrm{~m}$ to $2400 \mathrm{~m}$. It is a univoltine species, flying from the beginning of July to the end of July (RÁKOsY 2013). In Romania it shares its habitat and flies with P. cacalie (DINCĂ et al. 2008).

Distribution

It is a European endemic, Arcto-alpine species (Kudrna et al. 2011). It is located in the Pyrenees, the Alps, the Balkans, the Carpathians, northern Europe on the border between Norway and Sweden, as well as in Lapland. In Switzerland it is found at altitudes between 1000 and $2700 \mathrm{~m}$, and in Spain between 1500 and $2000 \mathrm{~m}$ (VAN SWAAY et al. 2014).

In Romania it was first seen in 1897 (CzeKELIUs 1897). It seems to be located only in the Southern Carpathians in the Bucegi and Fagaras Mountains (Fig. 22). It occurs at altitudes between 1700 and $2350 \mathrm{~m}$.

\section{Conservation}

The IUCN European Red List status of Pyrgus andromedae is least concern. In Romania $P$. andromedae is classified as vulnerable, but there is a data deficit on species status in the Carpathian Mountains. In known areas, the butterfly is common and shows stable populations (VAN SWAAY et al. 2014, RÁKosy et al. in press).

\section{Pyrgus cacaliae (RAMBUR, 1840)}

\section{Diagnosis}

It is very similar to $P$. andromedae. It has small spots on the back of the front wings. On the ventral side the spots are faded. There is no central basal patch on the dorsal side of the posterior wings - only two spots are present, $P$. andromedae has three spots (TOLMAN et al. 2001, Dincă et al. 2008).

Biology and Ecology

It populates with $P$. andromedae alpine and subalpine wet meadows, on acidic or basic substrate. It is a univoltine species and flies at the same time as $P$. andromedae from July to August (DINCĂ et al. 2008, RÁKosy 2013).

Distribution

It is an endemic species in Europe, found in the Alps, Southern Carpathians, Pyrenees. It is found at altitudes between 1800 and 2800m (Tolman et al. 2001).

In Romania was first reported in 1906 (CZEKELIUS 1907). According to the data, the butterfly is only found in the Southern Carpathians, in the Bucegi, Piatra Craiului and Fagaras mountains (Fig. 23). P. cacaliae is found at altitudes between 1750 and $2450 \mathrm{~m}$.

Conservation

The IUCN European Red List status of Pyrgus cacaliae is least concern. The Romanian Red List status is near threatened. Its worst threats are overgrazing and habitat loss (VAN SWAAY et al. 2014, RÁKOSY et al. in press).

\section{Pyrgus sidae (ESPER, 1784)}

Biology and Ecology

As habitats it prefers steppe grasslands, limestone or sandy substrate, as well as grasslands and hedgerows. Adults were spotted feeding with nectar on Achillea, Vicia, Marrubium, Scabiosa and Knautia. Adults have a quick flight and a territorial behavior, banishing any fly-off from their territory (RÁKOSY 2013). It is a univoltine species and flies from mid-May to the end of June.

\section{Distribution}

It has a palearctic distribution (KUDRNA et al. 2011). It was reported in western Spain, southeastern France, central Italy, Dalmatia, Greece, Macedonia, Albania, Bulgaria, Romania, Ukraine, Turkey, Asia Minor, Northwest Asia, South Ural, Northwest Kazakhstan and Western Tian Shan (Tolman et al. 2001, VAN SWAAY et al. 2010, RÁkosY 2013). It is found at altitudes between 50 and $1750 \mathrm{~m}$ (Tolman et al. 2001).

In Romania it is found in Dobrogea, the Eastern Carpathians, Transylvania and in the north of Oltenia. It seems to be missing from the south, east, west and north of the country (Fig. 24). It is found at altitudes between 50 and $850 \mathrm{~m}$.

Conservation

The IUCN European Red List status of Pyrgus sidae is least concern (VAN SWAAY et al. 2014). The species is classified as vulnerable nationally, endangered or near threatened taxon in some areas of Romania (RÁKosy et al. in press).

\section{Conclusions}

In the fauna of Romania 24 species of Skippers are present. Analyzing the altitude distribution, we have found that most of the Hesperiidae are present on foothills zone (14 species), followed by the lowlands zone with 6 species, montane zone with 2 species, subalpine and alpine zones each with one species (Fig. 1).

In Romania, only Heteropterus morpheus, Muschampia cribrellum, Muschampia tessellum and Pyrgus sidae are protected by law (GEO No. 57/2007, Annex 4B). There is no legislation at European level for the protection and conservation of the species in this lepidopteran family. Unfortunately, out of all the species present on the Romanian territory, only Muschampia cribrellum approaches the implementation of measures at European level, after the IUCN report from 2010, it was classified as near threatened, drawing attention to the habitat fragmentation and isolation of populations. This species has a total area populated on the European continent of only $42 \mathrm{~km}^{2}$ (VAN SwaAY et al. 2010).

$M$. cribrellum and $M$. tessellum meet all the criteria to be included in the list of species in the EU FFH Directive. Maintaining the two species in the EU 


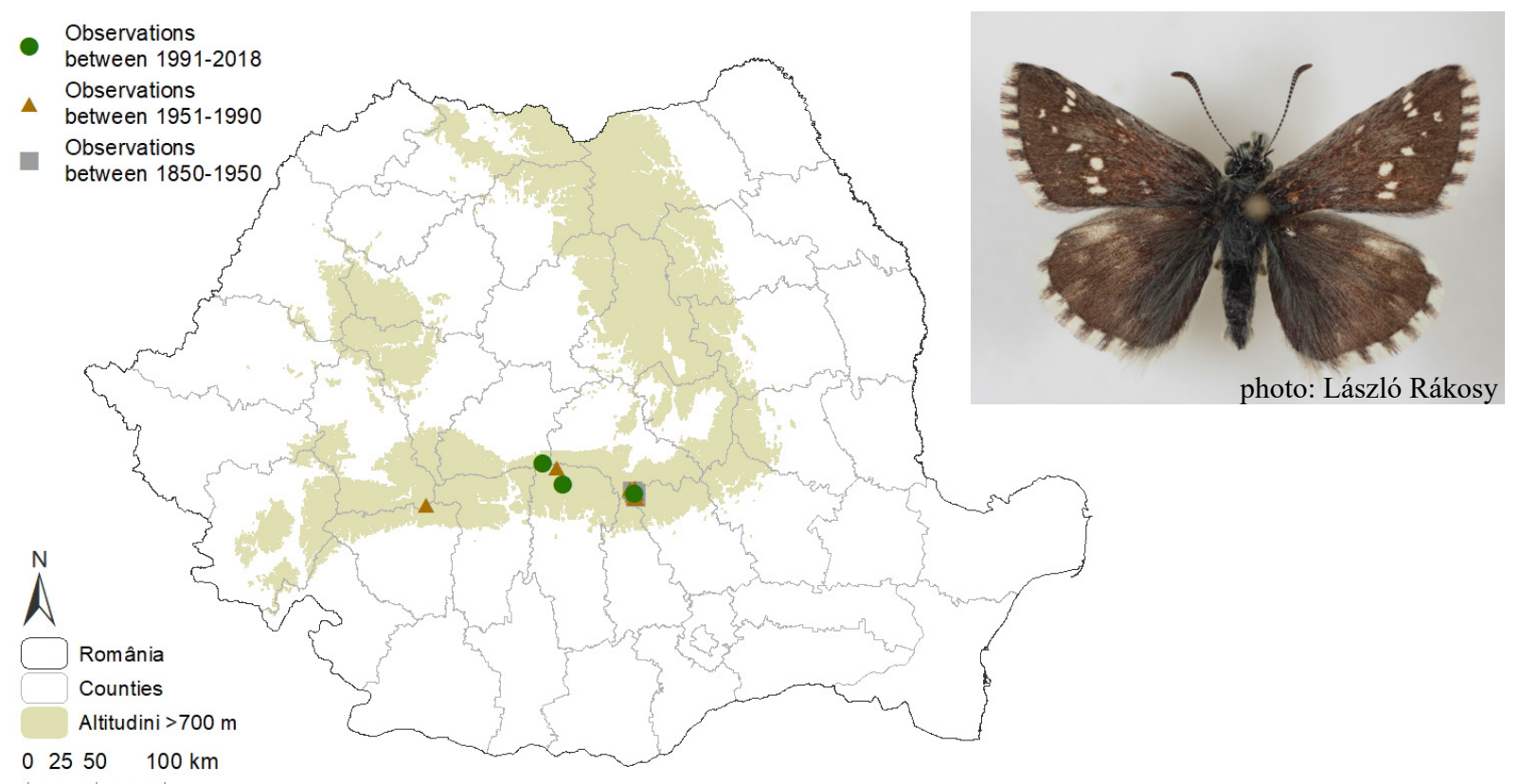

Fig. 23. Distribution map of Pyrgus cacaliae in Romania

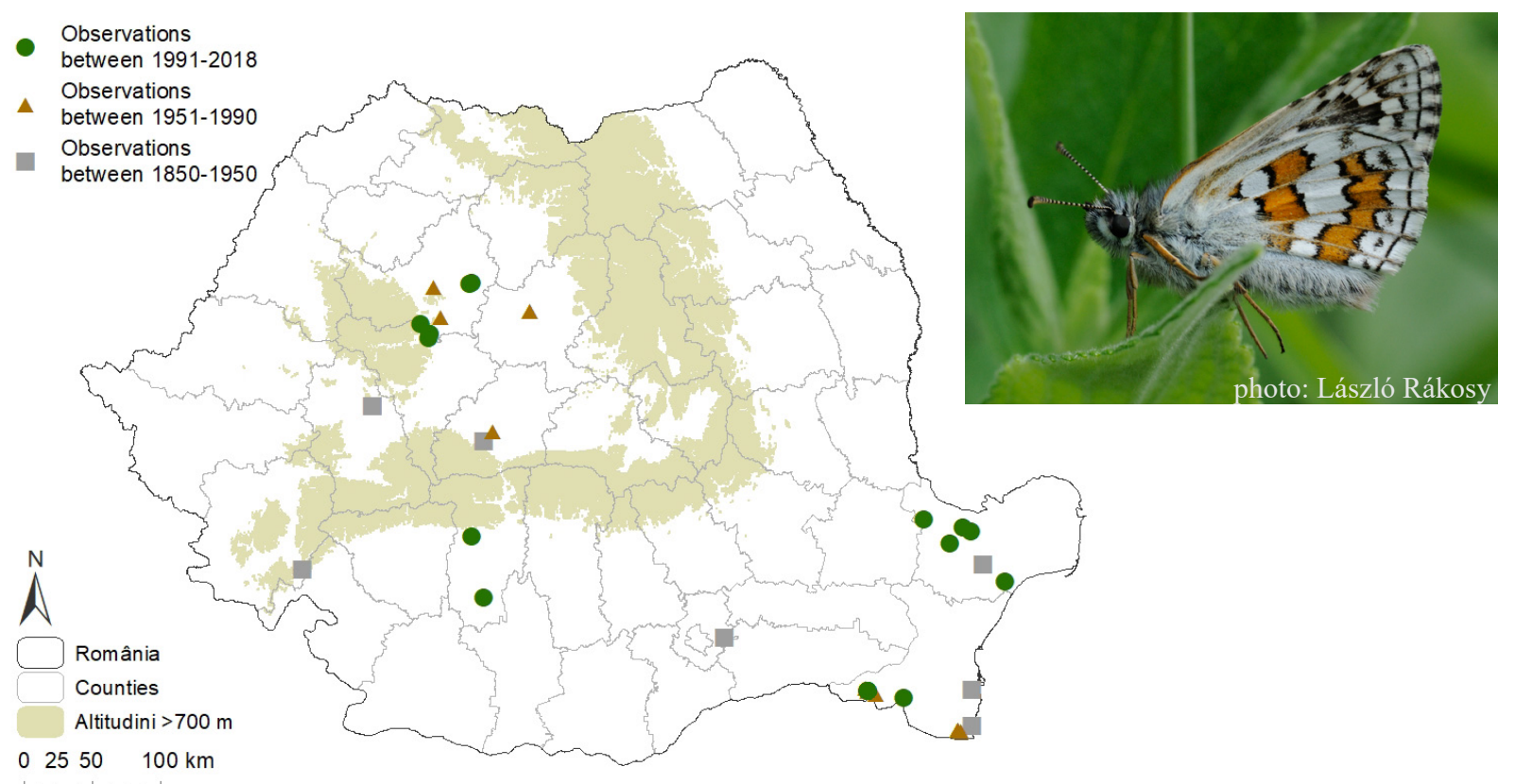

Fig. 24. Distribution map of Pyrgus sidae in Romania

depends on the protective and conservation measures that will be implemented in the countries where they are present. Unfortunately, in Romania this has been neglected so far.

Among the impact factors on the populations of Hesperiidae in Romania are: habitat transformation and alteration, urban development, intensification of agriculture, pollution, climate change and habitat fragmentation. Of all the impact factors, intensive grazing, with large flocks throughout the year is most likely to endanger the populations of Hesperiidae, because many of these species are dependent on the existence and quality of pastures. In order to protect and conserve the populations of Hesperiidae in Romania, it is important to raise awareness about this lepidopteran family and include them in the conservation measures.

\section{References}

Czekelius D. (1897) Kritisches Verzeichnis der Schmetterlinge Siebenbürgens. Verhandlungen und Mitteilungen des Siebenbürgischen Vereins für Naturwissenschaften zu Hermanstadt 47:1-78.

Beccaloni W.G. and Gaston J.K. (1995) Predicting the species richness of Neotropical forest butterflies: Ithomiinae (Lepidoptera: Nymphalidae) as indicators. Biological Conservation 71(1): 77-86.

Cremene C., Groza G., Rákosy L., Schileyko A., Baur A., ERhardt A. and BAur B. (2005) Alterations of Steppe-Like Grasslands in Eastern Europe: a Threat to Regional Biodiversity Hotspots. Conservation Biology 19(5): 1606-1618.

Dincă V., SzÉKely L., Kovács S., Kovács Z. and Vila R. (2008) Pyrgus andromedae (Wallengren, 1853) (Hesperiidae) in the Romanian Carpathians. Nota Lepidopterologica 31: 263-272.

Ebert G. and Rennwald E. (1991) Die Schmetterlinge Baden-Württembergs. Bd. 1.,Tagfalter I. Eugen Ulmer 
Verlag, Stuttgart.

ERhardT A. and Thomas J.A. (1991) Lepidoptera as indicators of change in semi-natural grasslands of lowland and upland Europe. In: Collins N.M. and Thomas J.A. (eds) The conservation of insects and their habitats. Academic Press, London, pp 213-236.

Fuss C. (1850) Verzeichniss der bis jetzt in Siebenbürgen aufgefundenen Lepidopteren. Verh. u. Mit. des Siebenbürg. Vereins für Naturwissenschaften 1: 54-64.

Garibaldi L.A, StefFan-Dewenter I., Winfree R., Aizen M.A., Bommarco R., Cunningham S.A. et al. (2013) Wild pollinators enhance fruit set of crops regardless of honey bee abundance. Science 339: 1608-1611.

Hallmann A.C., Sorg M., Jongejans E., Siepel H., Hofland N., Schwan H. et al. (2017) More than 75 percent decline over 27 years in total flying insect biomass in protected areas. PloS One 12(10): e085809.

Hesselbarth G., Van Oorschot H., Wagener S. (1995) Die Tagfalter der Türkei, Bd.1. Selbstverlag Sigbert Wagener, Bocholt, Deutschland.

Hijmans R.J., Cameron S.E., Parra J.L., Jones P.G. and JARVIS A. (2005) Very high resolution interpolated climate surfaces for global land areas. International Journal of Climatology 25: 1965-1978.

Kudrna O., Harpke A., Lux K., Pennerstorfer J., Schweiger O., Settele J. and Wiemers M. (2011) Distribution Atlas of Butterflies in Europe, Gesellschaft für Schmetterlingsschutz.

Kudrna O., Pennerstorfer J. and Lux K. (2015) Distribution Atlas of European Butterflies and Skippers. Wissenschaftlicher Verlag Peks, Schwanfeld.

Lafranchis T., Jutzeler D., Guillosson Y.J., Kan P. and KAN B. (2015) La vie des Papillons. Ecologie, Biologie et Comportement des Rhopalocères de France. Diatheo.

Ollerton J., Winfree R. and Tarrant S. (2011) How many flowering plants are pollinated by animals? Oikos 120: 321-326.

Oostermeijer J.G.B. and Van SwaAy C.A.M. (1998) The relationship between butterflies and environmental indicator values: a tool for conservation in a changing landscape. Biological Conservation 86: 271-280.

Pro Natura - Schweizerischer Bund für Naturschutz (Hrsg.)
(2000). Schmetterlinge und ihre Lebensräume. Arten, Gefährdung, Schutz. Schweiz und angrenzende Gebiete (in German).

RÁKosy L. (2013) Fluturii diurni din Romania (Butterflies of Romania), Mega Cluj-Napoca.

RÁKosy L. and GoIA M. (1997) Muschampia tesselum (HüBNER [1803]) şi M. cribrellum (EvERSMANN 1841) în fauna României (Lepidoptera, Hesperidae). Soc. Lep. Rom., Bul. Inf. Entomol. 8(3-4): 155-162.

RÁkosy L. and GoiA M. Catalogul Lepidopterelor României (in press).

RÁKosy L. and VARGA Z. (2000) Carcharodus orientalis Reverdin, 1913 und Melitaea (punica) telona Fruhstorfer, 1908 (Lepidoptera: Hesperiidae, Nymphalidae) in der Fauna Rumaniens. Entomologica Romanica 5: 45-49.

RÁKosy L., SzÉKely L., STĂNESCU M., DinCĂ V. Romanian Red List of Lepidoptera. Lista Roșie a lepidopterelor din România (in press).

SÁNCHEZ-BAYO F. and WyCKHUYS A.G.K. (2019) Worldwide decline of the entomofauna: A review of its drivers. Biological Conservation 232: 8-27, https://doi. org/10.1016/j.biocon.2019.01.020.

SchmitT T. and Rákosy L. (2007) Changes of traditional agrarian landscapes and their conservation implications: a case study of butterflies in Romania. Diversity and Distributions 13: 855-862.

Settele J., Steiner R., Reinhardt R., Feldmann R. and Hermann G. (2015) Schmetterlinge: Die Tagfalter Deutschlands, Verlag Eugen Ulmer, 256 p.

Tolman T. (2001) Lewington R., Butterflies of Britain \& Europe, Harper \& Collins Pub Ltd, 268 p.

Tuzov V.K. (1997) Guide to the Butterflies of Russia and Adjacent Territories (Lepidoptera, Rhopalocera). Volume 1: Hesperiidae, Papilionidae, Pieridae, Satyridae, Pensoft, Sofia - Moscow, 412 p.

Van SwaAy C., Wynhoff I., Verovnik R., Wiemers M., López Munguira M., Maes D., Sasic M., Verstrael T., Warren M. and SetTele J. (2010) The IUCN Red List of Threatened Species 2010.

Van SwaAy C., Wynhoff, I., Wiemers M., Katbeh-Bader A., Power A., Benyamini D. et al. (2014) The IUCN Red List of Threatened Species 2014.

\section{Cristina Costache}

Department of Taxonomy and Ecology Babeș-Bolyai University, Clinicilor 5-7 Cluj-Napoca, RO-400006, Romania

E-mail: costachecristina59@yahoo.com
Maria-Milena FILIP

Department of Taxonomy and Ecology Babeș-Bolyai University, Clinicilor 5-7 Cluj-Napoca, RO-400006, Romania

E-mail:filipmariamilena@gmail.com

\section{Andrei CRIŞAN}

Department of Taxonomy and Ecology Babeș-Bolyai University, Clinicilor 5-7 Cluj-Napoca, RO-400006, Romania

E-mail: andrei.crel@gmail.com

\section{László RÁKosY}

Department of Taxonomy and Ecology Babeș-Bolyai University, Clinicilor 5-7

Cluj-Napoca, RO-400006, Romania

E-mail: laszlo.rakosy@ubbcluj.ro
Received: 31.10 .2019

Accepted: 30.11 .2019

Published online: 31.12 .2019

Published: 31.12.2019

Online article number: ER23201904 
Appendix 1.

References used for generating Skippers distribution maps in Romania

Alexinschi Al. (1941) Elemente noi pentru cunoaşterea faunei lepidopterelor din Bucovina (Rădăuți). Analele Moldovei 1(1): 1-18.

Alexinschi Al. (1960) Contribuțiuni la cunoașterea faunei macrolepidopterelor din Masivul Rodna, cu considerații sistematice, ecologice și zoogeografice. Analele ştiinţifice ale Universităţii „Al. I. Cuza” din Iaşi, Sec. II, 6(3): 729-754.

AlexinsCHI Al. and KöNIG F. (1963) Contribuții la cunoașterea faunei de lepidoptere din Munții Lotru și Parâng. Soc. Șt. nat. și geograf. din R.P.R., Comunicări de Zoologie, 2: 132-149.

Alexinschi Al. and PeiU M. (1953) Contributii la cunoașterea faunei de lepidopterelor regiunii Iași (partea a II-a). Bul. șt. secț. șt. biol., agronom., geol. şi geograf 5(3): 487-509.

Alexinschi Al. and PeIU M. (1954) Contribuţii la cunoașterea lepidopterelor din Oltenia (comuna Căciulești și Pădurile Roaba și Sadova, reg. Craiova). Bul. șt. secț. șt. biol., agronom., geol. și geograf 6(1): 319-328.

Alexinschi Al., Olaru V., Gierling A., Căruntu V., Cristea V. and Constantinescu E. (1967) Contribuții la cunoașterea lepidopterelor din sudul Moldovei (Pădurea Gârboave), Studiul sistematic și zoogeografic (Nota I). Lucr. șt. Inst. Ped. Galați 1: 167-176.

Ardelean G. (1998) Fauna Jud. Satu Mare. Țara Oașului, Culmea Codrului și Cîmpia Someșului. „Vasile Goldiș” Univ. Press., p.155-217.

Balazs M. and Burnaz S. (2001) Date privind flora, vegetaţia şi fauna de lepidoptere diurne (Ord. Lepidoptera, S. ord. Rhopalocera) din zona Valea Dobrii şi rezervaţia forestieră de la BătrânaBunila (Munţii Poiana Ruscă, jud. Hunedoara, România), Soc. Lep. Rom., Bul. Inf., 12(1-4): 87-119.

BALINT Zs. (1980) Adatok a nagzlepkék elterjedéséhey Erdélzben (Lepidoptera). Folia Entomologica Hungarica „Rovartani Közlemények” 41(33), 2: 363366.

BALINT Zs. (1981) Adatok a nagzlepkék elterjedéséhey Erdélzben II. (Lepidoptera). Folia Entomologica Hungarica ,Rovartani Közlemények” 42(1): 227-251.

BALINT Zs. (1983) Újabb adatok a Keleti-Kárpátok nagzlepkefaunájának ismeretéhez (Lepidoptera). Folia Entomologica Hungarica „Rovartani Közlemények” 44, 2: 324-326.

BALINT Zs. (1995) Tavaszi lepidopterogiai megfigyelesek Dobrudzsaban. Folia Entomologica Hungarica 56: 228-230.

BÁLINT Zs. and Katona G. (2016) On the occurrence of Boloria aquilonaris Stichel, 1908 (insecta: Lepidoptera) in the southwestern carpathians (Banat, Romania). Studia Universitatis “Vasile Goldiş", Seria Ştiinţele Vieţii 26(3): 358-360.

BÁLINT Zs. and KATONA G. (2017) Historical records: Colias chrysotheme and C. palaeno in the valley of river Crişul Alb (Lepidoptera: Pieridae). Studia Universitatis "Vasile Goldiş", Seria Ştiinţele Vieţii 27(4): 260-262.

BÁlint Zs., Katona G., KarÁcsonyi K. P., Kertész K., PISZTER G. and BIRÓ L.P. (2014) Observations on the optical properties of an early summer blue butterfly community in Transylvania. Studia Universitatis "Vasile Goldiș", Seria Științele Vieții 24(4): 369-372.

Balletto E., Bonelli S. and Cassulo L.A. (2007) Insecta Lepidoptera Papilionoidea In: S. Ruffo, F. Stoch (Eds) -
Checklist and Distribution of the Italian Fauna. 10.000 terrestrial and inland water species 2 nd and revised edition. Memorie del Museo Civico di Storia Naturale di Verona pp. 257-261

Balletto E., Cassulo L. A. and Bonelli S. (2014) An annotated Checklist of the Italian Butterflies and Skippers (Papilionoidea, Hesperiioidea). Zootaxa 1: 1-114.

Boghean-Melconian V. (1981) Studiul Lepidopterelor (Rhopalocerae) dintr-o fitocenoza nou creata (zona forestiera defrișată) la Gornești (Jud. Mureș). Stud. Cerc. Biol. Seria Biol. Anim. 33(2): 173-177.

Burnaz S. (1992) Contribuţii la cunoaşterea faunei de macrolepidoptere din zonele carstice ale munţilor Metaliferi. Soc. Lep. Rom., Bul. Inf. 10(2): 19-32.

Burnaz S. (1993) Contribuţii la cunoaşterea faunei de macrolepidoptere a Măgurilor Devei (Jud. Hunedoara). Soc. Lep. Rom., Bul. Inf. 4(1): 3-11.

Burnaz S. (1995) Consideraţii ecologice şi zoogeografice privind fauna de macrolepidoptere a Cheilor Crivadiei (Masivul Şureanu). Soc. Lep. Rom., Bul. Inf. 6(1-2): 3350.

BURNAZ S. (2000) Data concerning the butterflies (Subord. Rhopalocera, Ord. Lepidoptera) from the eastern and north-eastern part of the Poiana Ruscă Mountains (Western Carpathians, Romania). Entomologica Romanica 5: 51-67.

Burnaz S. (2002) Fauna de lepidoptere diurne (Ord. Lepidoptera, S. ord. Rhopalocera) a judeţului Hunedoara, România. Consideraţii ecologice. Soc. Lep. Rom., Bul. Inf. 13(1-4): 41-66.

Burnaz S. (2005) Data about butterflies (Ord. Lepidoptera, S. ord. Rhopalocera) of Zlaşti Valley (Poiana Ruscă Mountains, Romania). Soc. Lep. Rom., Bul. Inf. Entomol. 16: 35-54.

BuRnAZ S. (2005) Macrolepidoptera species of the Crăciuneşti gorges and the neighbourhood of the localities Lunca and Băiţa (Metaliferi Mountains, Western Carpathians, Romania). Soc. Lep. Rom., Bul. Inf. Entomol. 16: 7-34.

BURNAZ S. (2007) Data concerning butterflies (Ord. Lepidoptera, S. ord. Rhopalocera) of Nandru Valley (Poiana Ruscă Mountains, Western Carpathians, Romania). Sargetia, Acta Mus. Dev. Ser. Sci. Nat. Deva 11(2005-2007): 128-148.

Burnaz S. (2007) Butterflies (Ord. Lepidoptera, S. ord. Rhopalocera) of Zlaști Valley (Poiana Ruscă Mountains, Western Carpathians, Romania). Sargetia, Acta Mus. Dev. Ser. Sci. Nat. Deva 11(2005-2007): 99-116.

Burnaz S. (2007) Contribuții la cunoaşterea faunei de macrolepidoptere din rezervaţia natural Dealul Bolii. Băniţa (Jud. Hunedoara). Soc. Lep. Rom., Bul. Inf. Entomol. 18: 53-78.

BuRNAZ S. (2007) Endemits and rare species in the Lepidoptera collection of the Museum of Dacian and Roman civilisation (Hunedoara County, Romania). Muzeul Olteniei Craiova, Oltenia, Studii și comunicări, Științele Naturii Tom XXIV/2008: 130-138.

Burnaz S. (2008) Faunistical and bio-ecological study of Rhopalocera species (Ord. Lepidoptera) of Muncelu Mic-Muncelu Mare-Poienița Tomii-Feregi zone (Poiana Ruscă Mountains, Romania). Sargetia, Acta Mus. Dev., Ser. Sci. Nat. 21: 115-141.

Burnaz S. (2011) Data about diurnal Lepidoptera fauna (Ord. Lepidoptera, S. ord. Rhopalocera) of the Poiana Ruscă Mountains (Western Carpathians, Romania); the area of Băuţar-Cornişor-Micota Valley (Caraş-Severin County). Soc. Lep. Rom., Bul. Inf. Entomol. 22: 79-88.

Burnaz S. and BaLAzs M. (2002) Argumente floristice şi 
lepidopterologice în favoarea includerii zonei carstice a bazinului Runcu-Govăjdie (Munţii Poiana Ruscă) în lista rezervaţiilor natural ale judeţului Hunedoara (România), Soc. Lep. Rom., Bul. Inf. 13(1-4): 27-40.

Burnaz S. and Balazs M. (2011) Contributions to the knowledge of diurnal Lepidoptera fauna of the NorthEastern part of Ţarcu Mountains (Southern Carpathians, Romania). Soc. Lep. Rom., Bul. Inf. Entomol. 22: 41-52.

CARAdjA A. (1905) Neuer Beitrag zur Lepidopterenfauna Rumäniens. Bulletin de la Société des Sciences de Bucarest-Roumanie 14: 227-243.

CAradja A. (1903) Neuer Beitrag zur Lepidopterenfauna Rumäniens. Bulletin de la Société des Sciences de Bucarest-Roumanie 12: 355-365.

Caradja A. (1929) Badereise eines Naturfreundes nach Tekirghiol. Deutsche Entomologische Zeitschrift ,Iris”, Dresd. 43: 41-65.

CARadja A. (1930) Beitrag zur Lepidopterenfauna der südlichen Dobrogea, insbesondere der sogenannten „Coasta de Argint”. Bull. Sect. Scient. Acad. Romaine 13: 31-51.

CARAdja A. (1931) Beiträge zur Lepidopterenfauna Grossrumäniens für das Jahr 1930. Memorille Sect. Scient. Acad. Rom., Seria III, Tomul VII, Mem. 8: 293332.

CARAdJA A. (1934) Neuer Beitrag zur Kenntnis der Lepidopteren-Fauna Rumäniens. Deutsche Entomologische Zeitschrift „,Iris” Dresd. 48:185-191.

CĂPuşe I. and Kovacs A. (1987) Catalogul colecției de lepidoptere „Laszlo Dioszeghy” de la muzeul județean Covasna, Sfântu Gheorghe, București.

Chimişliu C. (1990) Colecția de lepidoptere „M. Peiu” conservată la Complexul Muzeal Județean Dolj. Stud. și com. ,Oltenia” 7-8: 163-187.

ChimişLIU C. (2006) Lepidoptera (Insecta:Lepidoptera) from Romania preserved in the "Ion Firu" Entomological Collection from the patrimony of the Oltenia Museum Craiova. Entomologica Romanica 11: 55-68.

ChimişLiu C. and Goga C.I. (2005) Catalogul macrolepidopterelor Donaţiei „Ioan Stănoiu”, conservată în patrimoniul Secţiei de Ştiinţele Naturii a Muzeului Olteniei Craiova. C.M.Ş.N. „I. Borcea”, Bacău. Stud. şi com. 20: 103-120.

Ciochia V. and BARbU A. (1980) Catalogul colecției de lepidoptere „N. Delvig” a muzeului județean Brașov, Brașov.

CIOCHIA V. and BRĂTĂŞANU M. (1979) Contribuții la studiul lepidopterofaunei (Rhopalocera) din Rez. Nat. „Dealul Cetății” Brașov. Cumidava 12(3):175-185.

CordunEanu C. (1991) Contribuții la cunoașterea lepidopterelor din județul Botoșani (Diurna). Soc. Lep. Rom., Bul. Inf., Suppl. 1: 134-140.

Corduneanu C. (2011) Rezultatele aplicaţiei practice organizate cu prilejul Zilei Internaţionale a Biodiversităţii - 22 mai 2011 - în Rezervaţia „Zona umedă Orăşeni Vale”, județul Botoşani. Mnemosyne 2: 87-90.

Corduneanu C. (2012) Simpozionul Biodiversitate şi Dezvoltare Durabilă, ediţia a VI-a, 02 iunie 2012. Mnemosyne 3: 63 - 68 .

Corduneanu C. (2013) Simpozionul Biodiversitate şi Dezvoltare Durabilă, ediţia a VI-a, 02 iunie 2012. Mnemosyne 4: 75 - 80 .

Corduneanu C. (2014) Simpozionul Biodiversitate şi Dezvoltare Durabilă, ediţia a VIII-a, 07-08 iunie 2014. Mnemosyne 5: 31 - 36 .

Corduneanu C., Balan C. and Surugiu I. (2011) Observaţii diurne asupra faunei de lepidoptere (Insecta: Lepidoptera) din Rezervaţia Naturală „Valea lui David”, judeţul Iaşi. Mnemosyne 2: 51 - 57.

Corduneanu G. and Corduneanu C. (2013) Macrolépidoptères de la réserve forestière „Codrul Eminescian", (N.-E. de la Roumanie) (Insecta: Lepidoptera). Mnemosyne 4: 69 - 74.

Corduneanu C., Balan C. and Surugiu I. (2007) Lepidoptera of Humid Area „Orăşeni Vale” (Orăşeni Vale, Botoşani County, Romania). Entomologica Romanica 12: 113-120.

Craioveanu C. and Rákosy L. (2011) Fauna de lepidoptere din habitate semi-naturale montane ale zonei Muntele Băişorii (jud. Cluj). Soc. Lep. Rom., Bul. Inf. Entomol. 22: 89-103.

Cremene C., Rákosy L. and Erhardt A. (2002) Diversity of Macrolepidoptera in steppe habitats of Căianu Mic (Cluj). Entomologica Romanica 7: 5-14.

Cuvelier S., DincĂ V. (2007) New data regarding the butterflies (Lepidoptera: Rhopalocera) of Romania, with additional comments (general distribution in Romania, habitat preferences, threats and protection) for ten localized Romanian species, Phegea, 35: 93-115.

Cuvelier S., DincĂ V. (2009) New data on the Rhopalocera (Lepidoptera) of Dobrogea (south-eastern Romania). Phegea 37: 1-21.

Czekelius D. (1897) Kritisches Verzeichnis der Schmetterlinge Siebenbürgens, Verhandlungen und Mitteilungen des Siebenbürgischen Vereins für Naturwissenschaften zu Hermanstadt, 47:1-78.

Czekelius D. (1908) Beiträge zur Schmetterlingsfauna Siebenbürgens. Verhandlungen und Mitteilungen des Siebenbürgischen Vereins für Naturwissenschaften zu Hermanstadt 58: 153-164.

Czekelius D. (1917) Beiträge zur Schmetterlingsfauna Siebenbürgens. Verhandlungen und Mitteilungen des Siebenbürgischen Vereins für Naturwissenschaften, Hermannstadt 67(1-6): 1-56.

Czekelius D. (1935) Beiträge zur Schmetterlingsfauna Siebenbürgens. Verhandlungen und Mitteilungen des Siebenbürgischen Vereins für Naturwissenschaften zu Hermannstadt. Fortgesetzt: Mitt.der ArbGem. für Naturwissenschaften Sibiu-Hermannstadt 83-84(1): 59-69.

DincĂ V. (2006) The Macrolepidoptera (Insecta: Lepidoptera) from Istriţa Hill (Buzău County, Romania). Entomologica Romanica 10: 5-24.

Dincă V., Kolev Z. and Verovnik R. (2010) The distribution, ecology and conservation status of the Spinose Skipper Muschampia cribrellum (Eversmann, 1841) at the western limit of its range in Europe (Hesperiidae). Nota Lepidopterologica 33: 39-57.

DINCĂ V. and VILA R. (2008) Improving the knowledge on the Romanian Rhopalocera, including the rediscovery of Polyommatus amandus (Schneider, 1792) and an application of DNA-based identification. Nota Lepidopterologica 31: 3-23.

Dincă V., Székely L., Kovács S., Kovács Z. and Vila R. (2008) Pyrgus andromedae (Wallengren, 1853) (Hesperiidae) in the Romanian Carpathians. Nota Lepidopterologica 31: 263-272.

Dioszegy L. (1930) Beiträge zur Lepidopteren fauna des Retyezat-Gebirges. Publicații Muz., Jud. Hunedoara 5(27), 2: 1-23.

DioszegY L. (1930) Die Lepidopterenfauna des Retyezatgebirges. Verhandlungen und Mitteilungen des Siebenbürgischen Vereins für Naturwissenschaften zu Hermannstadt 79-80:188-289.

DioszegY L. (1934) Die Lepidopterenfauna des Retyezatgebirges, Nachtrag I. Verhandlungen und Mitteilungen des Siebenbürgischen Vereins für 
Naturwissenschaften zu Hermannstadt 83-84: 107-125.

FLECK E. (1899) Die Macrolepidopteren Rumäniens, In: Fauna de la Roumanie, Buletinul Societății de Sciințe 8(6): 682-773.

FLECK E. (1905) Die Macrolepidopteren Rumäniens, In: Fauna de la Roumanie, Buletinul Societății de Sciințe 13: 288-308.

Fotescu R. (1972) Contribiutii la cunoasterea faunei de Lepidoptere din bazinul Cernei şi împrejurimile orașului Hunedoara. Sargetia 9:117-130.

Fuss C. (1850) Verzeichniss der bis jetzt in Siebenbürgen aufgefundenen Lepidopteren. Verhandlungen und Mitteilungen des Siebenbürgischen Vereins für Naturwissenschaften zu Hermannstadt 1: 54-64.

GoIA M. and DincĂ V. (2006) Structura şi răspândirea faunei de lepidoptere diurne (Hesperioidea \& Papilionoidea) în împrejurimile municipiului Cluj-Napoca şi aspecte actuale ale influenţei antropozoogene asupra mediului de viaţă al acestora. Soc. Lep. Rom., Bul. Inf. Entomol. 17: 139-179.

GRECU M. (2002) Lepidoptere diurne (Hesperoidea, Papilionoidea) din zona localităţii Gidinţi (jud. Neamţ), Soc. Lep. Rom., Bul. Inf. 13(1-4): 118-188.

Hall C. A. (1991) Jr., (ed.) Natural History of the WhiteInyo Range, Eastern California. Berkeley: University of California Press.

HormuZAKI C. (1897) Die Schmetterlinge (Lepidopteren) der Bukowina, Theil 2. Verhandlungen der $k . u . k$. zoologisch-botanischen Gesellschaft in Wien 47: 120168.

HormuZaKi C. (1902) Neuere Macrolepidopteren-Funde aus Rumänien. Verhandlungen der ZoologischBotanischen Gesellschaft in Wien. Frueher: Verh.des Zoologisch-Botanischen Vereins in Wien. seit 2014 „Acta ZooBot Austria” 52: 563-567.

HormuzaKi C. (1903) Deuxieme Catalogue des Lepidopteres. Bulletin de la Société des Sciences de Bucarest-Roumanie 12: 133-140.

HoRMUZAKI C. (1904) Nachträge zur Lepidopterenfauna der Bukowina. Verhandlungen der k. u. k. zoologischbotanischen Gesellschaft in Wien 54: 422-447.

JudE C. TöröK S. and ILIE D. (2014) Diurnal Lepidoptera from Rapoltu Mare (Hunedoara County, Romania). Brukenthal. Acta Musei IX.(3): 491-502.

KöNIG F. (1975) Catalogul colectiei de lepidoptere a muzeului Banatului, Timișoara.

KÖNIG F. and WeIDLICH M. (2001) Zur Schmetterlingsfauna des Banater Karstgebietes in Südwestrumänien (Lepidoptera). Esperiana 8:732-746.

Kovacs S. and Kovacs Z. (1982) Lepidoptere diurne din jurul orașului Sf. Gheorghe. Stud. și Com. Soc. Șt. Biol. R.S.R. Filiala Reghin 2: 261-268.

Kovacs S. and Kovacs Z. (1992) Pyrgus armoricanus (Lepidoptera, Hesperiidae), une espece peux connue en Roumanie. Travaux du Muséum Nationale d'Histoire Naturelle "Grigore Antipa" 32:77-83.

Kovacs S. and Kovacs Z. (1994) The Lepidoptera-fauna of Sfântu-Gheorghe and surrounding areas (Transsylvania, Romania) III. Soc. Lep. Rom., Bul. Inf. 5(1): 41-47.

Kudrna O., Harpke A., Lux K., Pennerstorfer J., Schweiger O., Settele J. and Wiemers M. (2011) Distribution Atlas of Butterflies in Europe, Gesellschaft für Schmetterlingsschutz.

Lungoci A. (1973) Contribuții la cunoașterea faunei de lepidoptere din jud. Suceava. Stud. și com. șt. nat. 3: 389-394.

Manci C.O., Sitar C., Corduneanu C. and Balan C. (2015) First contribution to the study of lepidopteran fauna (Insecta: Lepidoptera) from Stânca, Iași, Moldova region (Romania). Mnemosyne 6: $31-47$.

ManN J. (1866) Aufzählung der im Jahre 1865 in der Dobrudscha gesammelten Schmetterlinge. Verhandlungen der $k$. u. $k$. zoologisch-botanischen Gesellschaft in Wien 16: 321-360.

Manoliu M.W. (1996) Contribuţii la cunoaşterea speciilor de macrolepidoptere diurne din zona Solca şi împrejurimile ei, formate din prelungirile Obcinei Mari (Obcina Trisiciori) (jud. Suceava). Soc. Lep. Rom., Bul. Inf. 7(1-2): 13-22.

Mıruț S. (1997) Lepidoptere din zona localităţii Bădeni (nord-estul Câmpiei Transilvaniei). Soc. Lep. Rom., Bul. Inf. 8(1-2): 67-77.

Miller Lee D. and Miller J.Y. (1972) New high-altitude Herperiinae from Mexico and Ecuador (Hesperiidae), $7 \mathrm{pp}$.

NADOLSCHI V. and ȘUGĂR M. (1975) Lepidopterele regiuni colinare subcarpatice ale jud. Bacău (Romania). Muz. Șt. nat. Bacău, Stud. şi com.: 107-146.

Nemeș I. (1970) Considerații sistematice, zoogeografice și ecologice asupra faunei lepidopterelor din rezervațiile științifice de la Frumoasa și Ponoarele, jud. Suceava (partea I). Stud. și com. ocrot. nat. Suceava: 115-138.

Nemeş I. (1974) Contribuţii la cunoaşterea lepidopterelor din jud. Neamț (partea I: Agapia). Stud. și cerc. geologie-geografie-biologie ser. bot.-zool., Muz. Șt. Nat. Piatra Neamț 2: 203-216.

Nemeş I. and PeIU M. (1971) Fauna de lepidoptere a masivelor Rarău-Giumalău (partea a II-a). Stud. com. șt. nat. Muz. jud. Suceava 2: 235-248.

Olaru V., Iordan M. and Mazilu H. (1965) Contribuțiuni la cunoașterea faunei macrolepidopterelor din Pădurea Letea. Contribuțiuni sistematice și zoogeografice (nota I). An. șt. Univ. Al.I. Cuza, sec. II 11(2): 321-332.

PapéC. Muntean I. and Rákosy L. (2013)Macrolepidoptere din Oltenia semnalate pe baza fotografiilor din natură. Soc. Lep. Rom., Bul. Inf. Entomol. 24: 68-84.

PeIU M. (1971) Contribuții la studiul lepidopterelor din jud. Bihor (loc. Tinca și Beiuş) Partea I. Lucrări Șt. Inst. Ped. Galați 5: 157-167.

Peregovits L. (1995) Data to the Macrolepidopterea fauna of Transylvania (Romania). I. Faunistical data. Folia Entomologica Hungarica „Rovartani Közlemények” 56: 163-178.

Peregovits L., Ronkay L. and Bálint Z. (2008) The Macroheterocera (Lepidoptera) Fauna of the Maramures Region, Rumania (Based on the Collectings of the Hungarian Natural History Museum, Budapest). Studia Universitatis "Vasile Goldiș", Seria Știintele Vieții (Life Sciences Series) 18 (suppl.): 313-336.

Popescu-GorJ A. (1967) Ord. Lepidoptera In: L'Entomofaune des forets du Sud de la Dobrogea. Travaux du Muséum Nationale d'Histoire Naturelle “Grigore Antipa” 7:181-212.

Popescu-Gorj A. (1970) Date privind lepidopterele de la Lacul Roșu și Cheile Bicazului. Stud. şi Cerc. Muz. Șt. Nat. Piatra Neamț 1: 331-355.

Popescu-Gorj A. (1975) Lepidoptera în Fauna, Serie momografică „Porțile de Fier” Academia R.S.R.: 214255.

POPESCU-GorJ A. (1976) Ord. Lepidoptera In: L'Entomofaune du Nord de la Dobrogea. La Zone Măcin-Tulcea-Niculițel. Travaux du Muséum Nationale d'Histoire Naturelle "Grigore Antipa” 17:159-172.

Popescu-GorJ A. and DrĂGHIA I. (1968) Ord. Lepidoptera In: L'Entomofaune d'ile de Letea (Delta du Danube). Travaux du Muséum Nationale d'Histoire Naturelle "Grigore Antipa" 9: 227-278.

Popescu-Gorj A., Olaru V. (1971) Date privind 
lepidopterele de pe grindul Caraorman (Delta Dunării), Inst. Pedag. Galați „Lucrări St.” 5:169-177.

Popescu-GorJ A., Olaru V. (1985) Date preliminare privind lepidopterele din insula Ostrovul Mare (Porțile de Fier II), „Drobeta”. Muz. Reg. Porțile de Fier 6: 325335.

RÁKosy L. (1980) Lucrare de diplomă, Cluj-Napoca.

RÁKosy L. (1982) Lepidoptere diurne din jurul orașului Sf. Gheorghe. Stud. și Com. Soc. Șt. Biol. R.S.R. Filiala Reghin 2: 261-268.

RÁKOSY L. (1988) A valuable collection of Lepidoptera in the Zoological Museum of the University in ClujNapoca. Studia Univ. Babeş-Bolyai. Biologia 32: 53-86.

RÁkosy L. (1995) Contribuţii la studiul faunei de macrolepidoptere din Munţii Parâng. Soc. Lep. Rom., Bul. Inf. 6(3-4): 179-188.

RÁKosy L. (1997) Macrolepidopterele din Parcul Naţional Retezat. În: Rákosy L. (Ed.) Entomofauna parcurilor naționale Retezat și Valea Cernei: 87-122, Cluj-Napoca

RÁKosy L. (2001) Diversität der Schmetterlinge (Lepidoptera) im Cheile Turzii Naturschutzgebiet (Siebenbürgen, Rumänien). Biodiversitatea lepidopterelor în rezervaţia Naturală Cheile Turzii (Transilvania, România), Entomol. rom., 6: 55-92.

RÁkosy L. Fauna de lepidoptere din satul Cobor (Transilvania, jud. Brașov), in press.

RÁKosy L. (2008) Fluturii și alte insecte, In: Monografia Rezervației Muntele Tâmpa, Ed. Pop G.O., Ed. Univesităţii „Transilvania”, Brașov.

RÁKosy L. (2009) Macrolepidoptere din perimetrul comunei Şinca Nouă (jud. Braşov). Soc. Lep. Rom., Bul. Inf. Entomol. 20: 5-26.

RÁKosy L. (2009) Ord. Lepidoptere (fluturi), In: Monografia Comunei Țaga, Ed. Mârza I., Primăria Comuna Țaga, Cluj-Napoca.

RÁKosy L. (2010) Lepidoptera, In: Situl Natura 2000 Cușma, Ed. Proorocu M., Beldean P., Crișan A., Risoprint, Cluj-Napoca.

RÁKosy L. (2013) Fluturii diurni din Romania (Butterflies of Romania), MEGA Cluj-Napoca.

RÁKosy L. and GoiA M. (1997) Muschampia tesselum (HubNer [1803]) şi M. cribrellum (Eversmann1841) în fauna României (Lepidoptera, Hesperidae). Soc. Lep. Rom., Bul. Inf. Entomol. 8(3-4): 155-162.

RÁkosy L. and GoiA M. Catalogul Lepidopterelor României in press.

RÁKosy L. and Kovacs S. (2001) Lepidoptere din Rezervaţia Naturală "Dealul cu Fluturi" de la Viişoara (Jud. Cluj). Soc. Lep. Rom., Bul. Inf. 12(1-4): 47-85.

RÁKosy L. and LÁszlófFy Z. (1997) Fauna de macrolepidoptere de la Fânaţele Clujului (Lepidoptera) (Cluj, România). Soc. Lep. Rom., Bul. Inf. 8(3-4): 165186.

RÁKosy L. and MANOLIU W.M. (1999) Lepidopterologische Biodiversität eines kleinräumigen steppenartigen Naturschutzgebietes in Siebenbürgn (Suatu, Transsylvaniein, Rumänien) Biodiversitatea lepidopterologică dintr-o rezervaţie naturală stepică, cu suprafaţă restrânsă din Transilvania (Suatu, România). Entomologica Romanica 4: 49-68.

RÁKosy L. and Neumann H. (1997) Macrolepidopterele din Valea Cernei. În: Rákosy L. (Ed.) Entomofauna parcurilor naționale Retezat și Valea Cernei: 123-151, Cluj-Napoca.

RÁKosY L. and SzÉKeLY L. (1996) Macrolepidopterele din sudul Dobrogei. Die Makrolepidoptera der Süddobrudscha (Südostrumäniens). Entomologica Romanica 1: 17-62.

RÁKosy L. and VARGA Z. (2000) Carcharodus orientalis
Reverdin, 1913 und Melitaea (punica) telona Fruhstorfer, 1908 (Lepidoptera: Hesperiidae, Nymphalidae) in der Fauna Rumaniens. Entomologica Romanica 5: 45-49.

RÁKosy L., Vicol V., SzÉKely L. and Goia M. (1997) Rezultatele taberei entomologice din Cheile Tişiţei Jud. Vrancea, 26.06-6.07.1997: Lepidoptera. Soc. Lep. Rom., Bul. Inf. 8(1-2): 18-32.

RÁKosy L. and WeBer W. (1986) Die Großschmetterlinge von Sighişoara (Schässburg) und Umgebung, Siebenbürgen, Rumänien. (Lepidoptera). Atalanta 16: 315-392.

RÁKosy L. and WIESER C. (2010) Diversität bei Schmetterlingen (Lepidoptera) im Gebiet von Rimetea (Eisenburg) (Transsylvanien, Rumänien). Soc. Lep. Rom., Bul. Inf. Entomol. 21: 36-83.

Rákosy L., Wieser C., Stangelmaier G. and Székely L. (1994) Rezultatele colectărilor realizate în a doua tabără entomologică a S.L.R. Munţii Făgăraş, 23-27(30) iulie 1994. 1. Lepidoptera. Soc. Lep. Rom., Bul. Inf. 5(3-4): 201-216.

Rebel H. (1911) Die Lepidopterenfauna von Herkulesbad und Orsova. Eine zoogeographische Studie, Annalea des K.K. Naturhistorischen Hofmuseum 25: 17-430.

RotschILD N.Ch. (1912) Beitrag zur Lepidopterenfauna der Mezozeg. Verhandlungen und Mitteilungen des Siebenbürgischen Vereins für Naturwissenschaften zu Hermannstadt 62(1): 1-32.

RuşTi D.M. (1992) Starea actuală a faunei de lepidoptere din Delta Dunării (Lepidotera: Rhopalocera și Sphinges \& Bombyces). Analele Stiințifice ale Inst. Delta Dunării, 1: 121-135.

SCHNeIDER E. (1970) Cîteva elemente sudice și estice în entomofauna colinelor stepice din împrejurimile Sibiului. Stud. şi Com. Șt. Nat. Muzeul Bruckental 15: 279-286.

SCHNEIDER E. (1984) Die Gross-Schmetterlinge der Sammlung Dr. V. Weindel. Stud. și Com., Muz. Bruckenthal, St. Nat. 26: 289-316.

Settele J. and Steiner R. (2015) Reinhardt R., Feldmann R., Hermann G., 2015. Schmetterlinge: Die Tagfalter Deutschlands, Verlag Eugen Ulmer, 256 p.

SitaR C. and Rákosy L. (2011) Macrolepidoptere din pădurea Popeni, Judeţul Sălaj. Soc. Lep. Rom., Bul. Inf. Entomol. 22: 59-68.

Skolka M. (1993) Contribuţii la cunoaşterea lepidopterelor diurne (Rhopalocera \& Gryphocera) din zona oraşului Blaj (Transilvania, România). Soc. Lep. Rom., Bul. Inf. 4(4): 223-233.

Skolka M. (1995) Date referitoare la lepidopterele din Dobrogea (Grypocera, Rhopalocera). Soc. Lep. Rom., Bul. Inf. 5(3-4): 223-243.

StANCĂ-Moise C. (2017) Study on the Macrolepidoptera collected from the Păltiniș (Sibiu County), existing within the collection of Dr. Viktor Weindel, Muzeul Olteniei Craiova, Oltenia. Studii şi comunicări, Ştiinţele Naturii Tom. 33, No. 2: 97-101.

STǍNESCU M. Catalogul colecției de lepidoptere „dr. Levente Székely”. Travaux du Muséum Nationale d'Histoire Naturelle “Grigore Antipa” (in press).

StĂnescu M. Colecția „Dr. doc. Aurelian Popescu-Gorj” (in press).

StĂNeSCU M. (1993) New Data Concerning Lepidoptera of Hagieni Forest Reservation (Dobrogea, Romania). Travaux du Muséum Nationale d'Histoire Naturelle "Grigore Antipa" 32: 273-284.

StĂNESCU M. (1995) The catalogue of "Ludovic Beregszászy" lepidopteran collection (Insecta: Lepidoptera). Travaux du Muséum Nationale d'Histoire Naturelle “Grigore Antipa” 35: 221-346. 
Stănescu M. The catalogue of „Dr. doc. Aurelian PopescuGorj" collection of lepidoptera (Insecta: Lepidoptera). Travaux du Muséum Nationale d'Histoire Naturelle "Grigore Antipa" (in press).

STĂNESCU M. (1997) New data concerning the lepidoptera fauna of southern Dobrogea (Romania). Travaux $d u$ Muséum Nationale d'Histoire Naturelle "Grigore Antipa" 39: 91-107.

StĂNESCU M., Ruşti D. (1997) The Lepidopterans (Insecta: Lepidoptera) of Igniș Plateau (Maramureș, Romania), Traveaux de Musée d'Histoire naturelle „Grigore Antipa”, 39:315-331.

STĂNESCU M. (2005) The catalogue of the „Ioan Lăzărescu” collection of Lepidoptera (Insecta) from the "Grigore Antipa" National Museum of Natural History (Bucharest). Travaux du Muséum Nationale d'Histoire Naturelle "Grigore Antipa" 47: 213-288.

StĂNESCU M., Ruști D. (1997) New data concerning the lepidoptera (Insecta) of Maramureș (Romania), Trav. Muz. Nat. Hist. Nat. „Grig. Antipa” 37:89-111, Buc.

STĂNOIU I.M. and BoBÂRnAC B. (1965) Cercetări asupra faunei de lepidoptere din Olteniei (nota I). Soc. de șt. nat. şi geograf. din R.P.R. 3: 215-226.

STĂNOIU I.M., BobÂRNAC B. and COPĂCESCU S. (1978) Noi date asupra macrolepidopterelor din Oltenia (nota V). Stud. și cerc., Com. de cult. şi ed. soc. al jud. Gorj: 227244.

STǍNOIU I.M., BobÂRnAC B. and Olaru N. (1973) Cercetări asupra faunei de lepidoptere din nord-estul Olteniei (nota I). Stud. si cerc. Com. de cultură și soc. Vâlcea: 219-225.

Szabo A. (1987) Studiul faunei de macrolepidoptere din împrejurimile localităţii Turulung (judeţul Satu Mare). Comitetul de Cultura si Edu. Socialista, Complexul Muzeal Judetean, 7-8: 427-446.

SzÉKelY L. (1992) Contribuţii la cunoaşterea faunei de macrolepidoptere din județul Botoşani (Moldova, România). Soc. Lep. Rom., Bul. Inf. 3(3): 7-17.

SzÉKELY L. (1996) Lepidopterele din sud-estul Transilvaniei (României) - Die Schmetterlingsfauna von Südostsiebenbürgen (Transsylvanien, Rumänien), Disz. Tipo., Săcele, 78 pp.

SzÉKELY L. (1999) Actualizarea sistematicii fluturilor diurni din România (Lepidoptera, Rhopalocera). Soc. Lep. Rom., Bul. Inf. 10(1-4): 225-226.

SzÉKely L. (2004) Contribuţii la cunoaşterea lepidopterelor din zona Vulcanilor Noroioşi (Berca, Judeţul Buzău). Soc. Lep. Rom., Bul. Inf. 14-15: 33-40.

SzÉKELY L. (2004) Noutăţi lepidopterologice din sud-estul Transilvaniei (Judeţul Braşov, România). Soc. Lep. Rom., Bul. Inf. 14-15: 41-56.

SzÉKely L. (2006) Parcul Naţional Ciucaş, Fauna de nevertebrate (Lepidoptera, Coleoptera, Odonata, Diptera, Gastropoda) pt. I.C.A.S. - Bucureşti.

SzÉKELY L. (2008) The Butterflies of Romania / Fluturii de zi din România. Brasov C2 Design.

SzÉKELY L. (2010) Lepidoptera species recorded from the North-Oltenia (Gorj county, Romania) (Insecta: Lepidoptera). Sargetia Sc. nat. Deva 1(22): 63-90.

SzÉKELY L. (2011) The Lepidoptera of Bucharest and its surroundings (Romania). Travaux du Muséum Nationale d'Histoire Naturelle “Grigore Antipa” 54 (2): 461-512.

SzÉKELY L. (2012) Evoluţia populaţiilor de fluturi diurni din zona Braşovului (sud-estul Transilvaniei, România) în perioada 1976-2012 (Lepidoptera: Rhopalocera). Mnemosyne 3: $53-60$.

SzÉKELY L. (2012) The macrolepidoptera (insecta) of central Dobrogea (Romania). Travaux du Muséum Nationale d'Histoire Naturelle "Grigore Antipa” LV(1): 125-166.

SzÉKELY L. (2013) Noi date asupra Macrolepidopterelor din Cheile Tișiţei (Munţii Vrancei, România). Soc. Lep. Rom., Bul. Inf. Entomol. 23: 59-74.

SzÉKELY L. (2016) Early spring lepidoptera (insecta: lepidoptera) from Dobrogea (Southeastern Romania). Brukenthal. Acta Musei: XI. 3.

SzÉKELY L. (2016) New and Rare Macrolepidoptera (Insecta) from Romanian Dobrogea (South-East Romania). Travaux du Muséum Nationale d'Histoire Naturelle "Grigore Antipa” 59(2): 195-230.

SzÉKelY L. and Stanciu M. (2001) Contribuţii la studiul faunei de lepidoptere din Câmpia Munteniei II. Soc. Lep. Rom., Bul. Inf. 12(1-4): 259-269.

SzÉKelY L., Haneschläger P. and Görbe R. (1998) Contribuţii la studiul faunei de lepidoptere din Câmpia Munteniei I. Soc. Lep. Rom., Bul. Inf. 9(3-4): 177-186.

SzÉKELY L., DincĂ V. and JuHÁsz I. (2011) Macrolepidoptera from the steppes of Dobrogea (south-eastern Romania). Phegea 39(3): 86.

Székely L., Kocs I., Szabó G. and Stanciu S. (2000) Rezultatele taberei entomologice S.L.R. (8-12 iunie 2000) de la "Poienile cu Narcise-Dumbrava Vadului" (Şercaia, jud. Braşov). Soc. Lep. Rom., Bul. Inf. 11(1-4): 63-79.

Tolman T. (2001) Lewington R., Butterflies of Britain \& Europe, Harper \& Collins Pub Ltd, 268 p.

Tuzov V.K. (1997) Guide to the Butterflies of Russia and Adjacent Territories (Lepidoptera, Rhopalocera). Volume 1: Hesperiidae, Papilionidae, Pieridae, Satyridae, Pensoft, Sofia - Moscow, 412 p.

Van Sway C., Wynhoff I., Verovnik R., Wiemers M., López Munguira M., Maes D., Sasic M., Verstrael T., Warren M. and Settele J. (2010) The IUCN Red List of Threatened Species 2010.

Van Swaay C., Wynhoff, I., Wiemers M., Katbeh-Bader A., Power A., Benyamini D., Tzirkalli E., Balletto E., Monteiro E., Karaçetin E., Franeta F., Pe’er G., Welch H., Thompson K., Pamperis L., Dapporto L., ŠAŠIĆ M., LóPEZ Munguira M., MiceVsKi N., DupOnT P., Garcia Pereira P., Moulai R., Caruana R., Verovnik R., Bonelli S., BeshKov S. (2014) The IUCN Red List of Threatened Species 2014.

VICOL V. (1986) Contribuții la studiul faunei de Rhopalocera (Lepidoptera) din județul Bistrița Năsăud, In: Lucr. a III-a Conf. de Entom. Iași, 20-22 mai 1983, pg. 141-148, R.S. Romania.

VizAUER T.C. (1997) Date asupra faunei de macrolepidoptere din zona localităţii Ocna-Dej. Soc. Lep. Rom., Bul. Inf. 8(3-4): 199-210.

VIZAUER T.C. (2009) Contribuţii la cunoaşterea faunei de macrolepidoptere din Câmpia Careiului (jud. Satu Mare). Soc. Lep. Rom., Bul. Inf. Entomol. 20: 141-163.

Wieser C. and RÁKosy L. (2000) Das Macin Gebirge (Rumänien, Nord-Dobrudscha). Ein durch hohe Biodiversität gekennzeichnetes Refugium reliktärer Arten. Fauna und Flora, unter besonderer Berücksichtigung der Schmetterlinge und der Vergetationsverhältnisse. Carinthia II, 190/110: 7-115. 